NBER WORKING PAPER SERIES

\title{
MARKETS IN CHINA AND EUROPE ON THE EVE OF THE INDUSTRIAL REVOLUTION
}

\author{
Carol H. Shiue \\ Wolfgang Keller \\ Working Paper 10778 \\ http://www.nber.org/papers/w10778
NATIONAL BUREAU OF ECONOMIC RESEARCH 1050 Massachusetts Avenue
Cambridge, MA 02138
September 2004

We have benefited from comments and discussions with Gregory Clark, Dean Corbae, Brad DeLong, Avinash Dixit, Michael Edelstein, Avner Greif, Peter Hansen, Jean-Laurent Rosenthal, Max Stinchcombe, and David Weil, as well as seminar participants at the International Monetary Fund, the Russell Sage Foundation, the World Bank thematic group on Poverty and Inequality, the European Science Foundation Conference on "Market Performance and the Welfare Gains of Market Integration in History" in Fiesole, the NBER Summer Institute 2004 Development of the American Economy and Economic Fluctuations and Growth meetings, the Macroeconomics Workshop at Brown University and Ohio State University, the Economic History Workshop at University California Berkeley, Columbia University, Stanford University, and University California Los Angeles, the Economics Department Seminar at University College London and the University of Texas, and the International Economics Field Seminar at the London School of Economics. We also thank Jörg Baten for the European weather data. Part of the paper was written while the first author was Visiting Scholar at the Russell Sage Foundation, and their hospitality is gratefully acknowledged. The views expressed herein are those of the author(s) and not necessarily those of the National Bureau of Economic Research.

(C2004 by Carol H. Shiue and Wolfgang Keller. All rights reserved. Short sections of text, not to exceed two paragraphs, may be quoted without explicit permission provided that full credit, including $\odot$ notice, is given to the source. 
Markets in China and Europe on the Eve of the Industrial Revolution

Carol H. Shiue and Wolfgang Keller

NBER Working Paper No. 10778

September 2004

JEL No. O1, N0, N7

\begin{abstract}
$\underline{\text { ABSTRACT }}$
Prevailing views suggest the Industrial Revolution began in Europe because markets had gradually become more efficient and by the 18th century the scope of economic activity was far larger than in other parts of the world. This paper compares the actual performance of markets in Europe and China, two regions of the world that were relatively advanced in the pre-industrial period, but would start to industrialize about 150 years apart. The analysis covers economies that account for about two-fifths of the world's population in the mid-18th century, and it considers some three centuries of data. Our findings suggest that relative levels of market function in China and Europe were similar prior to the Industrial Revolution. Higher efficiency in Europe is seen only in the nineteenth century when industrialization was already underway. Moreover, these improvements occurred in a dramatic and sudden fashion, further casting doubt on an evolutionary view of market development. Rather than being a key condition for subsequent growth, gains in efficiency appeared simultaneously with the turning point of modern growth. We discuss the implications of these findings for a number of explanations for long-run growth and the Industrial Revolution.
\end{abstract}

Carol H. Shiue

Department of Economics

University of Texas-Austin

BRB 2.126

Austin, TX 78712

shiue@eco.utexas.edu

Wolfgang Keller

Department of Economics

University of Texas-Austin

BRB 3.152

Austin, TX 78712

and NBER

keller@eco.utexas.edu 


\section{Introduction}

Recent interpretations of the Industrial Revolution suggest that it started around 1770 in Britain and spread to United States and Western Europe by the mid- $19^{\text {th }}$ century. ${ }^{1}$ The turning point of modern economic growth was a remarkable event because it was the first time in human history that per capita growth rates much above zero became sustainable over the long-run. How did a world of static expansion make its way to one of sustained increase in GDP per capita, and why did the Industrial Revolution start its spread from Europe and not elsewhere?

Prevailing views place a great deal of emphasis on how efficient markets and good institutions are necessary for modern growth. According to North and others, by 1700 Britain and the Netherlands had developed a set of institutions - common law, property rights, and nondistortionary pricing systems - that would lead to more efficient resource use and provide far greater incentives to make investments that would raise income per capita (North and Weingast 1989, North 1981, North and Thomas 1973). ${ }^{2}$ The Industrial Revolution is thus seen as the outcome of the evolution of European institutional forms, which has successfully taken root in other countries as well in the last two centuries. The historical record of Europe attests to an expansion of influence through trade and migration over long-distances (Chaswick and Hatton 2003, O’Rourke and Williamson 1999). European settlers, by bringing with them their heritage of good institutions, in some cases created the basis of long-run growth in these countries (Acemoglu, Johnson, and Robinson 2001). ${ }^{3}$

Empirical studies focusing on the importance of market-supporting institutions on

\footnotetext{
${ }^{1}$ The year 1770 is often chosen as the starting date of the Industrial Revolution because a number of key innovations, including the spinning jenny (1764), the water frame (1769), the steam engine (1774), and other inventions in the cotton industry as well as ironmaking were introduced around this time. See Crafts (1985) and Crafts and Harley (1992) for estimates on productivity growth rates between 1770 and 1861 in Britain. See Maddison (1989) on international income comparisons in the last three centuries.

${ }^{2}$ See North and Thomas (1973).

${ }^{3}$ Banerjee and Iyer (2002) show how different colonial policies have led to cross-regional income variation in India.
} 
economic incentives include Frankel and Romer (1999), who provide contemporary crosscountry evidence in support of a positive correlation between trade and growth, as well as the influential work of Hall and Jones (1999), and Rodrik, Subramanian, and Trebbi (2002). In the framework of Hall and Jones, countries that were more strongly influenced by Europeans in past centuries have social infrastructures more conducive to high levels of output per worker today. In addition to these studies, microeconomic studies that focus on private sector investment and the return to investment projects have generally found a positive association between government policies that protect property rights and returns (Isham and Kaufmann 1999, McMillan 2002).

This paper contributes to the literature on institutions and long-run growth by analyzing the relative efficiency of European markets over three centuries. Certainly, a more efficient economic system should be more productive. It is also very likely that large increases in incentives to invest occurred only after the onset of the Industrial Revolution, when the returns were much higher. The possible endogeneity of efficient markets and growth makes it difficult to ascertain causal direction. However, if better market-supporting institutions were a precondition for European growth, and European institutions were in some way exceptional, we would expect to find that European markets were more efficient compared to markets in nonEuropean economies well before Europe started to industrialize.

To see whether markets were very different in the pre-industrial world, this paper compares the actual efficiency of markets using data on the spatial dispersion of grain prices from the $17^{\text {th }}$ to the $19^{\text {th }}$ century. We focus on China and Europe, two regions of the world that were relatively advanced as of the mid- $18^{\text {th }}$ century, and yet would start industrializing about 150 years apart. The aim is to see whether European markets were already outperforming markets in 
China before the period of its industrialization, or whether large efficiency differences in commodity markets are a relatively recent phenomenon.

The analysis in this paper uses a number of empirical methodologies to assess different aspects of market efficiency. Overall, the methods give results that are consistent with each other. The main results of the paper suggest that as late as 1780 , markets in China were as efficient as those in Europe. The efficiency of English markets at this time, however, was greater than that found in the most advanced parts of Continental Europe as well as China. Furthermore, market efficiency in Europe improved between 1780 and 1830, and the improvement occurred dramatically and suddenly in comparison to what came before.

This paper relates to many contributions on the Industrial Revolution and cross-country comparisons, some of which are discussed further in section II. It is the first study, as far as we know, to provide a quantitative comparison of markets across Europe and most of China in the pre-industrial era. In addition, our starting point is somewhat different from the convention that assumes good institutions $=>$ market efficiency $=>$ growth. We do not assume that efficiency Europe was higher because it was the first to industrialize. In addition, efficiency may be a function of many factors, and these remain to be untangled. Thus, in our view: \{good institutions, geography, factor endowments, incentive to innovate, and other factors $\}=>$ market efficiency $=>$ growth. In addition to North's incentive arguments mentioned above, other writers have suggested numerous potential explanations for the Industrial Revolution, including geography (Diamond 1997, Sachs 2003), technological diffusion (Mokyr 1990), human capital accumulation (Inkster 1991, Mitch 1999), household labor organization (de Vries 1994), ecology (Wrigley 1988), religion and Protestant ethics (Weber 1903), and the discovery of new frontiers (Webb 1952). Institutional outcomes might have also arisen from interactions with these 
explanations (Acemoglu, Johnson, Robinson 2002, Sokoloff and Engerman 2000). Sokoloff and Engerman (2000), for example, focus on how local factor endowments exert an influence over institutional outcomes. A better understanding of changing patterns in market efficiency should provide a more complete picture of industrialization on many fronts as there are few explanations of growth that do not depend on the existence of, or have implications for, efficient markets.

Our analysis also sheds new light on a number of specific questions surrounding the industrial revolution. One is whether the Industrial Revolution was a uniquely British phenomenon, or whether the more advanced countries of Europe, such as France, China and other non-Western areas of the world were equally plausible contenders (Crafts 1995, Pomeranz 2000, Goldstone 2002). Overall comparisons of relative living standards remain elusive, in part because cross-country income differences in the $18^{\text {th }}$ century were relatively small, but there is general agreement that within China, the Yangzi Delta was one of the most developed. ${ }^{4}$ In a prominent recent study, Pomeranz maintains that whatever advantages England had over the Yangzi Delta, it was not in its markets, and that more generally, "China comes closer the neoclassical ideal of a market economy than Europe." the rest of Europe, and compares both to markets in the Yangzi Delta and in China overall.

Another issue on which we can bring new evidence to bear is whether the sources of growth in Europe might have originated from a long process of development stretching back for many centuries (perhaps as far back as the year 1000), or emerged rather recently in the last couple of centuries. ${ }^{6}$ Because we follow the same economies over several centuries, this reduces many important identification problems because persistent factors unique to Europe — such as

\footnotetext{
${ }_{5}^{4}$ For living standard comparisons, see for instance Allen (2002, 2001) and Bairoch (1975, 3-17).

${ }^{5}$ Pomeranz $(2000,17)$. See Huang (2002) on the "involution" thesis.

${ }^{6}$ There appears to be no evidence of there being any dramatic shifts in economic growth until at least the $19^{\text {th }}$ century. See Crafts $(1994,45)$.
} 
geography, customs, intellectual and ethical tradition, or language are held constant.

A comparison of the scope of incentives should have more general implications for existing theories on long-run economic growth to the extent that these theories depend on efficiency considerations. More generally, the question of market functioning is also important in furthering understanding of the origins of modern growth, how it can be sustained, and how it may be spread across economies today.

\subsection{Market efficiency and prices across locations: a simple framework}

We compare the efficiency of markets in China and Europe using prices in different locations. The failure of prices of identical goods to equalize between sites - the failure of the law of one price to hold - is indicative of limited trade possibilities. There are several notions of market efficiency in the literature, each of which focuses on different aspects as well as different underlying causes. To guide our discussion below, we introduce a simple general framework.

Consider an economy with many locations, $n=1, \ldots, N$, where consumers in all locations have the same preferences. In each location there are many producers with the same technology for producing a grain crop, which cannot be stored to the next period. Output is a function of the local harvest $\left(H_{n t}\right)$, which is affected by random shocks due to weather (climate, rainfall, etc).

All else equal, we expect that the local price in location $n$ at time $t$ can be written as

$$
P_{n t}=f\left(H_{n t}\right) \text {, with } f^{\prime}(.)<0 .
$$

With random weather shocks, local prices will vary randomly as well, unless trade between locations is feasible. In the extreme, if grain is perfectly tradable - there are no trade barriersits price in period $t$ will be equalized across locations: $P_{n t}=P_{t}, \forall n, t$, or, the law of one price holds. This is a standard interpretation of market efficiency. 
One reason why prices might not equalize is that the markets are geographically separated. Recent work in international trade suggests that some of its major features can be explained by geographic considerations (Fujita, Krugman, and Venables 1998). Take the widely-used case of iceberg transport costs, for example: exporters in location $n$ have to send $z>$ 1 units for every one unit of the good that arrives in the destination market $j$ (a fraction $1-1 / z$ melts in transit). With iceberg transport costs, the price of location $n$ relative to the price in region $j$ can be anywhere in

(2) $\frac{1}{z} \leq \frac{P_{n t}}{P_{j t}} \leq z$,

which corresponds to Heckscher's (1916) commodity points of trade. According to equation (2), the full equalization of prices cannot be achieved: the presence of transport costs means that prices in locations $n$ and $j$ are in equilibrium whenever they are in the range $(1 / z, z)$. As long as the pre-trade prices are such that

$$
\left|P_{n t}-P_{j t}\right|<z-1
$$

there will be no trade between locations $n$ and $j$ in period $t$.

Moreover, trade is more likely to occur within neighboring locations because transportation costs are relatively low. Let $d_{n j}$ be the distance between locations $n$ and $j$; we expect that $\mathrm{z}$ is a function of distance, $z\left(d_{n j}\right)$, with $z()>$.0 . This will mean that the equilibrium range of no trade is larger the larger is the distance between markets:

$$
\left|P_{n t}-P_{j t}\right|<\underset{(+)}{z\left(d_{n j}\right)-1}
$$

A natural measure of market efficiency in this context is the degree to which prices in locations $n$ and $j$ differ from each other for a given bilateral distance $d_{n j}$, because this can be 
viewed as an estimate of the transport cost function: the larger are the differences between $P_{n t}$ and $P_{j t}$ for a given distance, the lower is the efficiency of the market. Below, we present evidence on the width of the equilibrium price band for a given distance to compare market efficiency in China and Europe.

In addition to geography there are other factors that impact on the degree to which arbitrage will equalize prices between markets. ${ }^{7}$ The presence of national borders, for example, may be one important factor (Engel and Rogers 1996, Shiue 2004a). Governments often collect tariff revenues or impose other trade costs at national borders. These measures may be viewed as man-made transportation costs, and these can be easily accommodated in this framework. In addition, there may be other costs associated with trading across national borders, for instance, translation costs if different languages are spoken in the two locations $n$ and $j$. Let $\hat{z}_{n j}$ denote the trade costs between markets $n$ and $j$ conditional on distance. This suggests that $\hat{z}_{n j}=\hat{z}\left(\tau_{n j}, b_{n j}\right)$, with partial derivatives $\hat{z}_{\tau}>0, \hat{z}_{b}>0$, where $\tau_{n j}$ are trade policy barriers between markets $n$ and $j$, and $b_{n j}$ captures other national border-related trade costs.

Trade costs may incorporate other transactions costs. First, arbitrariness and the absence of the rule-of-law tend to raise transactions costs. If there is a positive probability of expropriation by the government, this will act as a tax on trade, just as the risk that a merchant might be robbed en-route to his destination will reduce trade. Both raise the expected costs of trade, and in our framework lead to a wider band of 'no trade'. Similarly, if property rights are not well-established or not well-enforced, this will reduce the efficiency of markets. For instance, if a buyer (from location $i$ ) lacks the means to ensure that a seller in location $j$ will not

\footnotetext{
${ }^{7}$ Anderson and van Wincoop (2003) survey several of the trade costs we discuss in the following.
} 
cheat once the former has made his payment, this will reduce the buyer's incentive to engage in the transaction - and this makes the band of no trade wider.

Another set of issues that might affect the efficiency of markets is the monopoly power of local incumbents. Local producers have an incentive to prevent the import of lower-cost goods, and may try to influence local officials to impose additional costs on suppliers from the outside. ${ }^{8}$ Powerful vested interests may lead to restricted market access, so that the equilibrium price band becomes wider and market efficiency declines. Summarizing, if we let $\widetilde{z}_{n j}$ denote the trade costs between markets $n$ and $j$ conditional on distance, the previous considerations suggests that in equilibrium, prices in $n$ and $j$ can lie anywhere in the range of $\widetilde{z}_{n j}{ }^{-1} \leq P_{n t} / P_{j t} \leq \widetilde{z}_{n j}$, and there will be no trade if and only if the pre-trade prices satisfy

$$
\left|P_{n t}-P_{j t}\right|<\widetilde{z}_{n j}-1, \quad \widetilde{z}_{n j}=\widetilde{z}\left(\begin{array}{c}
\tau_{n j}, \\
(+) \\
(+) \\
b_{n j}, a_{n j}, r_{n j}, v_{n j} \\
(+)
\end{array}\right) .
$$

In equation (4), $a_{n j}$ stands for risks associated with bandits, or more generally, anarchy, $r_{n j}$ denotes strong property rights, and $v_{n j}$ captures the strength of vested interests (e.g., guilds), with the expected partial effects given below each variable.

Our comparison of market efficiency captures the joint effect of many of the key arguments of why the Industrial Revolution first took root in Europe, and not in China, even though it does not distinguish between them. First, Smithian arguments of the size of the market are captured directly by the degree of price dispersion conditional on distance. Differences in market size may in turn be determined by the existing quality and costs of transportation technology in Europe, versus China. A number of recent growth theories suggest that the rate of

\footnotetext{
${ }^{8}$ In the case of grain, local officials tried to keep markets open for imports, at least in times of bad harvests, because they feared food riots and a general loss of legitimacy. During normal times foreign suppliers often faced special permits and other regulation that were only suspended in times of crisis (Seiffert 1893), consistent with the influence of vested local interests.
} 
innovation is a function of market size because the return to innovation increases with market

size. ${ }^{9}$ Second, the trade policy influence on the costs of arbitrage in equation (4) captures the degree to which European national versus Chinese provincial governments imposed trade restrictions that distorted or prevented trade.

Third, the border variable captures a host of different influences, which seem on the whole to favor China, since it was a unified empire at the time. ${ }^{10}$ The fourth influence, anarchy, is often associated with the extent of rule of law, government expropriation, general security, and the absence of war. The fifth variable, property rights, discussed earlier, has been emphasized by North and Thomas (1973), in their argument that weak property rights restrict the effective size of the market, and thereby limit the scope of specialization and the division of labor. And sixth, it has been frequently noted that vested interests, for instance guilds, might have been a major force of retardation in some economies. ${ }^{11}$

\subsection{Measuring market efficiency}

A number of different methods are used to assess market efficiency. First, we study the variability of grain prices in a given location one at a time. Segmented markets tend to show relatively high price variability compared to integrated markets because the local price is determined by random shocks to the local harvest (see equation 1). This single-market measure has the advantage of capturing the influence of other markets without imposing a particular trade structure.

Our second method is to examine the relationship between pairs of markets. Specifically,

\footnotetext{
${ }^{9}$ See Aghion and Howitt (1998) for an overview, and Jones (1995) for a critique.

${ }^{10}$ Note, however, that different spoken dialects are used in China.

${ }^{11}$ Olson (1965), Landes (1969); the latter for instance argues that it required the guilds to move aside for competition to become self-enforcing in Europe; page 19.
} 
the strength of bilateral price correlation conditional on distance is used to study the width of the no trade band (see equation 4). ${ }^{12}$ If there were differences between Europe and China in terms of the leading suspected causes for the Industrial Revolution, our discussion above indicates that their combined effect can be gauged from a comparison of market efficiency (measured by $\widetilde{z}$ ).

Third, we employ cointegration techniques to look for evidence of a long-run equilibrium relationship between two price series as an additional way of comparing market efficiency in the two continents. If there is a long-run equilibrium relationship-i.e., there is a tendency to move to the band of no trade in equation (4) - this provides evidence on the strength of the forces of market arbitrage. A specific version of this cointegration approach allows also for formal testing of the (absolute) law of one price (this corresponds to $\widetilde{z}=1$ ) and the estimation of the speed of adjustment to the long-run equilibrium. These three methods produce largely the same basic result, and we believe that other standard methods would yield similar conclusions as those found in this paper. ${ }^{13}$

The focus is on the grain market not only because it is of major importance in preindustrial economies, but also because it remains an important market once the process of industrialization has begun. While cotton textiles, the energy generating industry (steam engine), and the iron and steel industry dominated the growth of manufactured output, there is ample evidence suggesting that productivity growth occurred in the agricultural sector as well, albeit in

\footnotetext{
${ }^{12}$ One reason for studying price correlations instead of absolute price gaps lies in the multitude of currencies in $18^{\text {th }}$ century Europe, together with imperfect data on exchange rates. One can show that for a given distance, a smaller (larger) range in terms of absolute prices implies a higher (lower) correlation of prices. For an analysis of absolute price gaps for a more limited set of markets in $19^{\text {th }}$ century Europe, see Shiue (2004a).

${ }^{13}$ Each of the three methods - although rarely all three - has been widely used in historical or contemporaneous studies of market integration, of the law of one price, as well as of purchasing power parity (e.g. O'Rourke and Williamson 2004, Persson 1999). Other approaches to estimating market efficiency include threshold autoregression models (Taylor 2001) and spatial regression models (Keller and Shiue 2003); we think that these as well as other methods would yield the same qualitative conclusions as this study.
} 
a more broadly diffused manner. ${ }^{14}$ One might ask whether the efficiency of grain markets has implications for the efficiency of markets in these economies overall. In general, although the Industrial Revolution is commonly linked to manufacturing industries, as long as the source of change was economy-wide in nature, its benefits should accrue to commodity trade in all products. This would be especially true if the basis of Britain's efficiency were in economywide institutions, advanced transport and communication, and other shared technologies. Moreover, linkages between the primary and secondary sectors, as well as general equilibrium effects more generally (specifically, between goods and factor markets) also suggest that processes affecting incentives will not be bottled up in a single market. ${ }^{15}$ Thus, a comprehensive comparison of grain markets will shed light on economy-wide levels of market efficiency.

Before presenting the empirical results, we give some background on China and Europe in the $18^{\text {th }}$ century, and discuss the major characteristics of the data.

\section{Background on the economies: China and Europe}

The land area under analysis is roughly evenly divided between Chinese provinces and European nation-states. In terms of population, available estimates indicate that the population in the 10 Chinese provinces in our sample in the late $18^{\text {th }}$ century was about 120 million. The population of Europe at this time might have been 120 to 150 million (Durand 1960, McEvedy and Jones 1978).

Although foreign trade in the $18^{\text {th }}$ century was not significant, China's expansive empire meant that even domestic trade involved distances large enough to be equivalent to international

\footnotetext{
${ }^{14}$ Harley (1999) attributes more than one-third of all productivity growth in the British Industrial Revolution to agriculture.

${ }^{15}$ One reason, for example, why capital markets are important is that they allow more efficient trade in commodities, permitting to import goods at some time while exporting at another.
} 
trade in Europe. Trade between the fertile agricultural areas in the upper reaches of the Yangzi River and the urban regions of Shanghai at the Yangzi Delta involved covering distances of at least 1,200 kilometers, approximately the distance of the trade route between Antwerp and Vienna. The maximum distance between markets in our sample for Europe is about 1,400 and for China about 1,850 kilometers.

Grain was the most important commodity produced and traded in the pre-industrial world. In China in the $18^{\text {th }}$ century, as in Europe, the labor force was predominately engaged in agriculture. The majority of the population was engaged in small-scale, producer-cum-consumer farming, and available estimates suggest that agricultural output made up at least $60 \%$ of GNP in pre-industrial economies. ${ }^{16}$ Grain was an important commodity not only in overall output but in consumption as well. The share of cereals in the diet of urban dwelling northern Europeans, who it is said ate more meat and fish than their southern neighbors, was still nearly $60 \%$, a figure also likely to be significantly lower than for the average farmer. ${ }^{17}$

There is ample evidence that the Chinese state as well as individual European governments tried to regulate grain supplies. China had state-run granaries for the purpose of price stabilization, although the maintenance of these granaries was in serious decline by the late $18^{\text {th }}$ century. ${ }^{18}$ In Europe, policies were used to help stabilize bread prices, and the presence of many political borders likely made it easier in Europe, than in China, to regulate commodity traffic. In both regions, it was the case that the fixing of grain prices by decree was seldom carried out. Overall, it is unclear which economy had more regulations, or was more successful

\footnotetext{
${ }^{16}$ See Chang $(1962,291-325)$ for his estimate on the share of agriculture in China in the $18^{\text {th }}$ century. Li, B. (1998) cites Qing observers who put the percent of the population engaged in agriculture in the Yangzi Delta at 50\% during the late $17^{\text {th }}$ century. In Britain in 1700, approximately $61.2 \%$ of male labor was employed in agriculture and $65 \%$ of total income (from industry and agriculture) was in agriculture; see Table 3.1 in Crafts (1994).

${ }^{17}$ Spooner (1961).

${ }^{18}$ See Will and Wong (1991), Shiue (2004b and 2004c).
} 
in carrying out stated objectives.

Our analysis focuses on grain prices as opposed to the volume of grain traded for two reasons. First, trade volume statistics are very spotty, and the resulting evidence would be weak at best. ${ }^{19}$ Second, even if we had good data, there need not be a relationship between trade volumes and market efficiency. In terms of the framework of section 2 , the volume of grain that needs to be traded between markets $n$ and $j$ in order to reach the band of no trade (e.g., equation 2) may be large or small, but either is associated with the same market efficiency (the width of the band).

We now turn to a discussion of the data set.

\section{Prices in China and Europe}

This paper employs data on market prices in a large set of locations throughout Europe and China. ${ }^{20}$ Figure 1 gives a graphical summary of the years of data available for each series; the range is from the $15^{\text {th }}$ to the $20^{\text {th }}$ century, although we limit the empirical analysis to the $17^{\text {th }}$ to $19^{\text {th }}$ century. The prices for the European markets are for wheat, the dominant grain in most regions. The closest homogenous good that matches this characteristic in China is rice, and for this reason we select the ten main rice producing provinces of China. ${ }^{21}$

The Chinese series consists of 121 locations; at 54 years of data, it is relatively short compared to the time series availability of some European markets. However, the geographical

\footnotetext{
${ }^{19}$ In Europe, rough calculations suggest that $1 \%$ of total consumption of the Mediterranean area was traded in the $16^{\text {th }}$ century, and the situation may have remained much the same in the $17^{\text {th }}$ century (Braudel 1992, 127). In China, the Yangzi Delta alone - with an area of 43,000 square kilometers and an estimated population in the range of 20-36 million inhabitants in the $18^{\text {th }}$ century-may have imported as much as one-quarter of its total grain consumption (population estimates for this period are imprecise; these are reported in Li, B. 1998, 19).

${ }^{20}$ With the exception of a portion of the London series, the European sources employed in this paper are all official records of transactions at markets with many buyers and sellers (so-called mercuriales price series). Also the prices for China are market prices; see, e.g., Wilkinson (1969).

${ }^{21}$ For the Chinese province of Hunan, we have information on both wheat and rice prices; a comparison of these data suggests that grain type, wheat in Europe and rice in China, does not have a major influence on our results.
} 
coverage of the Chinese price reports is much broader than it was in the European sample. The Chinese data captures 121 contiguous markets, a region comprising about $60 \%$ of the empire and including the most commercialized areas as well as relatively remote regions. The combined geographical scope of the European markets is narrower. Another difference is that nearly all the European price data up to the $18^{\text {th }}$ century are from regions that were fairly important markets. Only in the $19^{\text {th }}$ century does more contiguous data become available, which, as in the case for France, begins to include records from small markets as well. Some of the smaller cities in the Grand Duchy of Mecklenburg (located to the east of Hamburg), for which we have price records, were not particularly central points of commerce either.

Table 1 summarizes the key characteristics of the price series. The sources for each series give quite detailed information on the method of collection of each series and the units of account. Due to changes in units of account, all prices have been converted to common units of currency per volume (or weight) within a series. We have not tried to account for changes in the value of the currencies over time. Missing information on the (typically) silver content of the coins would necessarily lead to low-quality estimates. However, while our overall sample stretches over three centuries, the window of time for which we compare market efficiency are typically only 25 years long. For this and a number of other reasons, we do not think that inflation has a major impact on our findings. ${ }^{22}$

The most important differences among the various price series have to do with the method of collection and the degree of aggregation in the price information. What allows us to measure the impact of differences in these respects is the fact that there are only a small number

\footnotetext{
${ }^{22}$ For instance, this analysis avoids times of high and volatile rates of inflation, such as the Napoleonic Wars. In addition, prices were broadly trending upwards over time in both Europe and China, and it is not clear for which markets inflation was higher (if any). On inflation in China, see Wang (1992). We have also investigated the importance of inflation for our results by allowing for a trend in the deterministic component of the cointegration relationship (equation 7 below); formal tests generally reject that hypothesis.
} 
of different ways to collect market prices, and that there is enough data such that we can always find several markets sharing commonalities in their method of recording prices. The key differences are given in Table 1. Columns I through III give information on the location of the market in today's country, the name of the location in historic times, and the source of the data. Columns IV through IX provide summaries of the differences among each series, which include the frequency of observation (IV), the years available (V), the method of collection (VI), whether minimum and maximum prices are recorded (VII), whether there is spatial aggregation in the method of collection (VIII), and whether quantity data has been used to compute price averages (IX). Additional details about these differences and references to units of each series used in this paper can be found in the Data Appendix.

\section{Empirical Results}

\subsection{Single-market price volatility}

Many previous studies have used the volatility of the price in a given market as an indication of how segmented one market is from other markets, on the rationale that volatility should decline as markets become more connected to other markets through trade (e.g., McCloskey and Nash 1984). During the period 1742 to 1785 , the average coefficient of variation for 15 European markets for which there is data is equal to 0.188 , with a standard deviation of 0.051 . For the 121 markets in Chinese prefectures during the same period, the average coefficient of variation is equal to 0.131 (standard deviation of 0.029 ).

Instead of price levels, another widely used measure is the volatility of period-to-period price changes (e.g., Engle and Granger 1991). Let $p_{t}$ denote the log of the price in period t. Under the assumption that markets are efficient, prices fully reflect all known information, and 
the best forecast of the price next period is the price in the current period. This forecast will be correct up to a random shock $\left(\varepsilon_{t}\right)$, which is white noise. This random walk model is thus given by

$$
p_{t+1}-p_{t}=\varepsilon_{t} \quad \text { for } t=1, \ldots T-1
$$

where $\varepsilon_{t}$ is independent and identically distributed with zero mean and variance $\sigma_{\varepsilon}{ }^{2}$. The conditional mean is

$$
E\left[p_{t+1} \mid I_{t}\right]=p_{t},
$$

with $I_{t}$ being the information set at time t. Allowing for seasonal effects extends equation (5) to

$$
p_{t+1}-p_{t}=\varphi^{\prime} S_{t}+\varepsilon_{t},
$$

where $S$ is a $(1 \times 2)$ vector of indicator variables.

After estimating the parameters $\varphi$ by ordinary least squares, we compute the standard deviation of the estimated residual $\hat{\varepsilon}_{t}$ as our measure of volatility. On average, this volatility in the 15 European markets is 0.127 , with a standard deviation of 0.025 . For the 121 Chinese markets, the volatility is on average 0.092 , with a standard deviation of 0.020 . Both the comparison of the price levels as well as of first differences suggests that the price volatility for Chinese markets is comparable to or lower than price volatility among European markets. From these results, it appears that the degree of market efficiency in Europe, as captured by these volatility measures, was not exceptionally greater in comparison to that in China.

\subsection{The correlation of prices across market pairs}

The price correlation between two markets gives another measure of market efficiency. 
Higher correlation suggests more trade links, all else equal. Generally, price correlations between markets decline as distance increases, because the costs of transport rise with distance. In comparing efficiency across market pairs, it is useful to condition on transport costs and thus hold distance constant. ${ }^{23}$ The average bilateral correlations are listed in Table 2a for the years 1742-95. We have formed a number of samples with markets selected for comparability and commonality of period. For instance, the table gives the correlations for the provincial capital prefectures of China. These places were important from a political point of view, but were not necessarily well-linked by trade routes. For comparison, the table also tabulates correlations for the Yangzi Delta region and among the Yangzi River prefectures.

For Europe, the table includes results for 15 markets in today's Germany, France, Belgium, Netherlands, Austria, Luxembourg, Germany, and France (Table 2a, bottom). The choice of locations is to some extent determined by the availability of data. For example, the years over the Revolutionary and Napoleonic Wars are for the most part avoided. The sample was selected, however, to include the most advanced regions of Europe, or the early industrial nations. As the first country to industrialize, England is a particularly interesting case, and is presented separately from the results for Western Europe as a whole, along with France, generally considered the most advanced on the Continent (Table 2a, lower part).

The results of Table 2a confirm that, as expected, price correlations decline with distance. There is also heterogeneity in market efficiency conditional on distance, both in China as well as in Europe. For instance, in China the range of average correlations for distances between 150 and 300 kilometers is from 0.81 to 0.58 , while in Europe the average correlations for distances between 450 and 600 kilometers vary from 0.71 to 0.53 . The following Table $2 \mathrm{~b}$ shows results

\footnotetext{
${ }^{23}$ Distance might be correlated with some factors determining $\widetilde{z}$ in equation (4) as well. If so, by conditioning on distance we hold constant more than transport costs. This effect, however, should be of second order.
} 
for price correlations in Europe starting in the $17^{\text {th }}$ and $19^{\text {th }}$ century, which are results that preand post-date, respectively, those of Table $2 \mathrm{a}$. These two tables contains too many figures to fruitfully discuss all possible comparisons that might be of interest, and below we will highlight a number of them using graphs. In addition to average price correlations for a given distance, we have also analyzed computed the gradient of price correlation with distance using OLS regressions. These results complement our analysis and are presented in Table 3.

Turning to Figure 2, this shows the scatterplot of price correlation and distance for 15 European cities in the period 1770-1794. It also shows the price-distance relationship for two samples of Chinese markets: those located on or near the Yangzi River, and the provincial capital markets. ${ }^{24}$ If the results for the two Chinese samples are indicative of the range of efficiency in China's markets, it would seem that market efficiency in Western Europe was roughly comparable to the efficiency of Chinese markets. This is suggested by Figure 2, since as the figure shows, it is possible to identify markets in China where the price-distance relationship lies above and where it lies below that for the European markets.

Moreover, it appears that the degree of market efficiency attained in Europe as of the late $18^{\text {th }}$ century had been roughly at that stage for some time. Figure 3 compared the estimate between the late $17^{\text {th }}$ century $(1692-1716)$ and the late $18^{\text {th }}$ century $(1770-1794)$. The markets underlying the sample for the two periods are not identical due to data availability, and there are fewer series in the earlier sample, but there does not seem to be marked improvements in market efficiency over this period. In particular, the estimated level and slope of the relationship between correlation and distance for the later period lies fully within the confidence bands of the

\footnotetext{
${ }^{24}$ The maximum distance of coverage for the European markets is about 1000 kilometers. Given that the Chinese sample includes markets with distances up to about 1,850 kilometers, it is possible to choose many different market group configurations for the Chinese sample.
} 
earlier period. It appears that levels market efficiency can remain in relative stasis for extended periods of time.

The lack of any dramatic shifts in market performance in Europe over the 80 years before 1770 is in contrast to the changes that would be seen in the 50 years after 1770 . Figure 4 shows the price correlation estimates for 15 cities across Western Europe between the years 1825 to 1849. The regression line and confidence band are above all other market groups (including those for China). This figure also suggests that changes to the level of market efficiency can make dramatic improvements over a relatively short period of time. ${ }^{25}$

As noted above, the availability of data in Western Europe tends to be limited to the more important urban centers of Europe. The data for China is different because it is fairly comprehensive, and includes not just important marketing centers, but also relatively remote places where one would not expect much trade. Figure 5 and Figure 6 show bilateral correlations for all 121 markets in China, given by the 7260 circles in the plots. The 15 European markets are shown by the 105 squares, and they lie within the Chinese markets in Figure 5. Figure 6 provides a striking contrast to Figure 5-it is clear that Europe has moved ahead. While we do not have reliable data for China in the later period, we expect that there was no equal advancement in market efficiency over these 45 years in China.

Figure 7 compares the bilateral price correlation among the markets of the extended Yangzi Delta with England. The maximum distance for the two samples is about 600 kilometers. The regression line for the English sample is located above the estimate for the Yangzi Delta sample at virtually all distances. For distances up to 400 kilometers, the

\footnotetext{
${ }^{25}$ This improvement may be related to the reduction of trade barriers, of which the German Zollverein was the major example. At the same time, the Zollverein liberalizations did not start until 1834, they came in many rounds throughout the $19^{\text {th }}$ century, and did not affect all of our European markets (see Shiue 2004a); which means that its effect on our findings may have been limited.
} 
confidence band of the extended Yangzi Delta crosses the English sample, indicating that the two samples are not distinguishable for greater distances.

The same statement could not be made for similar distances within nations of Continental Europe. Figure 8 plots the price correlation and distance diagram for 10 cities in central France, for an area considered to be a fairly well-integrated region within France. The plot, which also gives the confidence bands for the French sample, together with the Yangzi Delta sample, suggests that the two samples are indistinguishable at all distances.

Markets in England as of 1770 thus appear to have had an advantage in market efficiency, and were not only more integrated than in the most developed regions of China, but also compared to regions in Western Europe as a whole. By the early $19^{\text {th }}$ century, markets across Europe improved to an extent that it looked similar to England.

\subsection{Cointegration among markets}

This section compares market efficiency in China and Europe by employing time series techniques. The concept of cointegration was introduced by Granger (1981), Engle and Granger (1987) as a way of characterizing the long-run relationship among a set of variables. Formally, cointegration refers to a situation in which a set of variables $y_{n}, n=1,2, \ldots, N$, is each integrated of order $d>0$ (or, $I(d)$ ), while a linear combination of the $y_{n}$ variables is integrated of order $(d-$ $b),(I(d-b))$, with $b>0$. Of particular interest is the case where $d=1$ and $b=1$, that is, where each variable by itself is non-stationary (it has a unit root), while a linear combination of the variables is stationary; this case is denoted as $C I(1,1)$.

In our context, a linear combination of grain prices that is stationary when each individual price is not would support the idea that the grain prices evolve in a long-run 
relationship in which arbitrage (that is, trade) prevents the prices to drift arbitrarily far apart. In terms of the above framework, cointegration among two series means that there exists an attractor - a line, or, due to transportation costs, risks, and other factors, a band; see equation (2) - towards which the prices tend to attract over time. In this sense, testing for cointegration provides evidence on market efficiency.

We have used two different methods to study cointegration across the markets of our sample. Primarily, we rely on the methodology proposed by Engle and Granger (1987). This approach is quite robust and requires relatively few distributional assumptions. We have also employed Johansen's (1988) maximum likelihood method, which can give additional insights, although at the cost of being more restrictive. ${ }^{26}$ Both of the methods lead to the same qualitative findings, and in the following we focus on Engle and Granger's (1987) technique. Appendix A discusses results using Johansen's techniques.

Engle and Granger's (1987) method may be described as follows. Consider the price series in location 1 and in location $2, p_{1 t}$ and $p_{2 t}$, where for any location $n, p_{n t}=\ln P_{n t}$, and $t=1, \ldots, T$. The question is whether or not a long-run (cointegrating) relationship exists between $p_{1 t}$ and $p_{2 t}$. First, assume that both $p_{1 t}$ and $p_{2 t}$ are known to be $I(1) .^{27}$ Then, we estimate the following OLS regression:

$$
p_{1 t}=\beta_{0}+\beta_{1} p_{2 t}+e_{t} .
$$

If $p_{1 t}$ and $p_{2 t}$ are cointegrated, there will be some $\beta_{1}$ and $\beta_{0}$ such that $p_{1 t}-\beta_{0}-\beta_{1} p_{2 t}=0$ is

\footnotetext{
${ }^{26}$ Johansen's method allows estimating both the cointegrating rank and the model parameters simultaneously using an efficient one-step procedure, whereas Engle-Granger's two-step procedure can entail a loss of efficiency. Another advantage of Johansen's method is that it allows for testing restrictions on the long-run relationship and for estimating the speed of adjustment in a maximum likelihood framework. At the same time, Johansen's method requires errors to be normal, which is not necessary in the Engle and Granger approach; see, for example, Maddala and Kim (1998) for more discussion.

${ }^{27}$ We have tested for that. Typically the null hypothesis of I(1) cannot be rejected using standard unit root tests.
} 
satisfied. Here, $e_{t}$ is the equilibrium error, and the vector $\beta, \beta=\left[\beta_{0} \beta_{1}\right]^{\prime}$ is the cointegrating vector. The constant $\beta_{0}$ captures long-run differences in the price levels. ${ }^{28}$ The slope coefficient $\beta_{1}$ is an estimate of the degree to which prices in the two markets are moving together $\left(\beta_{0}=0\right.$ and $\beta_{1}=1$ means the absolute law of one price holds, while $\beta_{0} \neq 0$ and $\beta_{1}>0$ means the relative law of one price holds). Engle and Granger's approach to testing for cointegration between $p_{1 t}$ and $p_{2 t}$ is to test whether $e_{t}$ is stationary: the stationarity of $e_{t}$ implies that the linear combination of prices $p_{1 t}$ and $p_{2 t}$ is stationary, or, $\left(p_{l t}, p_{2 t}\right)$ are cointegrated.

Our test of whether the estimated residual $\hat{e}_{t}$ of equation (7) is stationary is based on the unit root test proposed by Dickey and Fuller (1979):

$$
\Delta \hat{e}_{t}=\delta_{1} \hat{e}_{t-1}+\varepsilon_{t} .
$$

Under the null hypothesis that $\hat{e}_{t}$ is $I(1)$, the parameter $\delta_{1}$ is equal to zero; failing to reject that $\delta_{1}=0$ provides evidence that $\hat{e}_{t}$ is $I(1)$ and $p_{1 t}$ and $p_{2 t}$ are not cointegrated. More generally, the stronger is the evidence that $\delta_{1}$ is below zero-i.e., the lower is the t-statistic of $\hat{\delta}_{1}$-the stronger is the evidence that $p_{I t}$ and $p_{2 t}$ are cointegrated. We compare the efficiency of markets in China and Europe by comparing the evidence for cointegration in terms of this t-statistic for a number of different samples.

This method is implemented with a number of modifications. First, the dependent variable lagged once is added as a regressor in (8) to reduce problems due to serial correlation (turning this into an Augmented Dickey Fuller $[\mathrm{ADF}]$ test) $:^{29}$

\footnotetext{
${ }^{28}$ One reason why we need a constant is that some of the prices are quoted in different currencies and quantity units; as noted above, we do not have reliable exchange rates for all times and currencies in Europe.

${ }^{29}$ Information criteria that trade off the increase in fit with the reduction in degrees of freedom are generally recommended for choosing the number of lags to be included (Engle and Yoo 1987). We have used Schwarz Bayes
} 
Second, we include seasonal effects in the cointegrating relationship, equation (7), as they are important for agricultural goods. Third, we reduce the effect from outliers in (7) by adding indicator variables to the deterministic component for periods with exceptionally strong price changes. $^{30}$ Because these modifications affect the distribution of the critical values of hypothesis tests based on the t-statistic of $\hat{\delta}_{1}$, the available t-statistics do not apply anymore. For this reason, we look for general patterns in the ADF t-statistics as opposed to testing sharp hypothesis. $^{31}$

Turning to the results, in Figure 9 the average ADF t-statistic is shown by distance class for European markets during the years 1742 to 1795 . Seven non-overlapping distance classes are used, and with 15 markets, there are a total of 210 bilateral relations. ${ }^{32}$ We find the lowest ADF t-statistics for the smallest distances — less than 150 kilometers — which is what one would expect: the evidence in support of cointegration is strongest among relatively near markets. As bilateral distance increases, the evidence for the existence of long-run relationships among markets generally falls (higher values for the t-statistic of $\hat{\delta}_{1}$ ). This is illustrated by the logarithmic trend line for the European sample, also shown in Figure $9 .{ }^{33}$

Information Criterion (SIC; see, e.g., Maddala and Kim 1998, 77). For these data, the SIC generally suggests one or zero lags of $\hat{e}_{t}$ should be included.

${ }^{30}$ We treat a price change that is larger than one standard deviation as an outlier; some experimentation with other definitions indicates that the main results are not sensitive to this choice.

${ }^{31}$ MacKinnon (1991) allows computing approximate small-sample critical values, which we report below. Asymptotic critical values are tabulated in Engle and Yoo (1987). Note that the standard ADF critical values do not apply because $\hat{e}_{t}$ is estimated.

${ }^{32} \mathrm{We}$ do not restrict the estimate of the cointegrating vector (if one obtains $\hat{\beta}_{1}$ in one direction, one expects $\hat{\beta}_{1}^{-1}$ in the other); in our case, not imposing this restriction plays no major role for the conclusions.

${ }^{33}$ While the average ADF t-statistic appears to be a good measure of the evidence for cointegration among different markets, we have also computed other statistics, such as the median. Table 4 presents both for comparison, 
The lower line in Figure 9 summarizes the evidence on cointegration for the English markets (40 counties, plus London) in our data set. Clearly, for a given distance, the average ADF t-statistic is considerably below that for the European sample, or, the evidence for cointegration among the English markets is higher than for the European sample as a whole. ${ }^{34}$ This difference may in part be due to the fact that the comparison is between markets in different countries versus markets in one country (England), and, that border effects are important. However, we have seen above that the English markets are relatively efficient even if compared with other within-country samples, such as France. The relatively strong evidence for cointegration for England is highly consistent with the results from bilateral price correlations. More generally, these results highlight that there was a substantial amount of heterogeneity in efficiency within Western European markets in the second half of the $18^{\text {th }}$ century.

How does the evidence on cointegration in Europe compare with that for China during this period? Figure 10 shows how the ADF t-statistic varies with distance for the same sets of Chinese prefectures, as in section 5.2 above; the values for the European 15 markets (from Figure 9) are plotted again for comparison. For distances less than 150 kilometers, the evidence for cointegration is stronger in Europe than in China, while for distances of 300-900 kilometers, market efficiency in China appears to be ahead of Europe (on average). This is true of the China River sample as well as the expanded Yangzi Delta markets (note that there are no markets in this group greater than 750 kilometers in bilateral distance).

indicating that average and median are similar in this case. This table also reports the standard error of the average ADF t-statistic. Analogous tables accompanying Figures 10-12 are not included for space reasons, but are available upon request. Formal cointegration tests are not reported because - as noted above - there are no exact critical values. However, as a point of reference, based on MacKinnon's (1991) analysis, we compute approximate critical values of $-3.95(-3.40)$ at the $1 \%(5 \%)$ significance level.

${ }^{34}$ We have adjusted the t-statistics for the English sample for comparability with the European sample based on MacKinnon (1991). He shows that critical values for these cointegration tests are a function of $\mathrm{T}$, the time series length (on average, $\mathrm{T}=50$ for the English and $\mathrm{T}=80$ for the European market pairs; there are two monthly observations per year). In essence, it becomes easier to find evidence in favor of cointegration the larger is $\mathrm{T}$, so the critical values need to be adjusted to hold the significance level constant. 
The group of Chinese provincial capital markets gives regional diversity. The ADF tstatistic for this group lies always below that of the average European city (see Figure 10). This is interesting because even though this sample represents the major city in each province, the sample covers areas in China that, at that time, are clearly not among China's most advanced regions. The Chinese provincial capitals are also far apart, so it does not encompass distances of less than 150 kilometers, where market efficiency in Europe appears to be relatively high.

Finally, Figure 10 includes the average ADF t-statistic for the sample of all 121 Chinese markets. The key results are best gleaned from the trend lines provided in Figure 11. The evidence on cointegration from all 121 Chinese prefectures is weaker than in Europe for distances up to about $400 \mathrm{~km}$, and stronger than in Europe above that threshold. Figure 11 also shows the trendline for the Yangzi Delta prefectures. There, the evidence for cointegration is stronger than for Europe for all distances except those less than 150 kilometers.

Overall, the evidence for cointegration is consistent with the analysis above in sections 5.1 and 5.2: there does not appear to be a large difference in terms of market efficiency between China and Western Europe. But what about Britain? Figure 12 suggests that markets within Britain were different from the average European markets. In addition, Figure 12 shows the average cointegration statistics for the English markets, compared to the Yangzi Delta prefectures. The evidence for cointegration among English markets is stronger than among Yangzi Delta markets at all distances (up to 600 kilometers, the maximum distance between markets in England). This supports the hypothesis that English markets were more efficient than those in the most advanced part of China at this time.

Thus, these results suggest that while the Yangzi Delta had similarly efficient, or possibly 
more efficient markets compared to Western Europe as a whole in the later $18^{\text {th }}$ century, Britain's markets in the last three decades of the $18^{\text {th }}$ century were more efficient still. ${ }^{35}$ The gap between Britain and Western Europe was not large in the sense that the continent attained the level of integration that Britain had at the end of the $18^{\text {th }}$ century within the next several decades. Figure 12 shows the cointegration statistics for European markets for the years 1825 49, after the dust following the Napoleonic Wars had settled. Market efficiency was substantially higher in Europe in the first half of the $19^{\text {th }}$ century than in the late $18^{\text {th }}$ century, but this improvement led to a level of market efficiency that was not so different from Britain during the years 1770 to 1794 .

Before we summarize and evaluate the results, we turn to a possible objection of our analysis. The issue is whether our results may be driven by different weather patterns in Europe and China. With agricultural products such as wheat and rice, weather will typically have a major influence on the local price (equation 1). If weather would change quite differently across geographic space in China than in Europe, this could lead to substantial differences in spatial price correlations without any implications for trade and market efficiency. For this reason, we have compared historical weather data for China and Europe to see whether the spatial weather patterns could bias our comparison of market efficiency. Our analysis suggests that spatial weather patterns have not been very different in the two continents, and specifically, it is unlikely that the influence of weather has favored China over Europe in our comparison; see Appendix B.

\footnotetext{
${ }^{35}$ The period for which we have English prices is slightly later than the Chinese sample (the samples are centered around the year 1782, versus 1769 , respectively), but ten to fifteen years per se does not make a big difference, as we have confirmed by restricting the analysis for China to 1770-94.
} 


\section{Summary and discussion}

The above sections have used measures that exploit variations in cross-sectional price as well as those that consider variations over time to measure the degree to which markets are connected. The results are robust to several different well-known methods that assess market efficiency.

First, we find comparable degrees of market efficiency in China and Europe in the late $18^{\text {th }}$ century. For short distances, Europe appears to have been slightly ahead of China-these may correspond to distances within countries. Over longer distances, however, China was ahead. We do not find evidence to support the idea that Europe (in a sample that includes locations in the Netherlands, Britain, and Belgium, for example), had exceptionally efficient markets by 1700 . We do not see exceptional efficiency in European markets even at the end of the $18^{\text {th }}$ century, when Europe was on the verge of an industrial revolution. This contradicts historical analyses that suggest good institutions created exceptionally efficient markets in Europe early on.

Second, we find that market efficiency in Britain stands out among Western European countries in the late $18^{\text {th }}$ century, and it is also higher than in China's Yangzi Delta. That Britain was ahead of Western Europe as a whole at this late date is an important result. In particular, the lateness of the improvements in efficiency contradicts interpretations that place much emphasis on the early, gradual, and definite institutional advantages that Europe had on this front. It also shifts the focus away from the importance of slow-moving institutional improvements that were 
accumulated bit by bit since medieval times. ${ }^{36}$ Even assuming that Britain and the Netherlands were both pre-industrial and on par as of 1700, as has been claimed by North and others, the brevity of time during which the paths of Britain and other Western European countries then diverged may be taken as further evidence against theories that rely on highly persistent factors that change only very gradually (e.g., morals, religion). ${ }^{37}$ Generally, the large difference between Britain and Continental Europe suggests that in so far as the origins of the Industrial Revolution are concerned, we need to look for differences between the two regions. The differences may help to provide a theory in which over a relatively short period of time (17001770) conditions emerge such that Britain industrializes while Western Europe as a whole does not.

Third, Continental Europe did develop more efficient markets compared to China, but it acquired them swiftly and relatively late, in the $19^{\text {th }}$ century. Sudden change in markets might come about if the sudden change in Western European markets may be linked to a driving force that can generate very rapid changes. It may be that an important difference between the institutions of China and Europe was that in addition to offering equal incentives to efficiently trade, European institutions also allowed flexibility and rapid changes to be made to existing institutions. In addition, there may also be yet another non-institutional factor more directly responsible for the sudden changes that we observe. Technological innovations, for instance, could lead to sharp discontinuities in efficiency. ${ }^{38}$

\footnotetext{
${ }^{36}$ In a statement that seems to echo North's thesis, E. Jones maintains, "Political insecurity and institutional rigidity in feudal and medieval times so obviously held back productive investment that the course of their reduction is virtually a history of development." Jones $(2003,93)$.

${ }^{37}$ Certainly, complex systems can generate vastly different dynamics due to only a small change in very short time (bifurcations). At the same time, we are not aware of evidence on such highly non-linear effects in this context. Most of the empirical literature uses linear (not non-linear) regressions (e.g., Acemoglu, Johnson, and Robinson 2001).

${ }^{38}$ Mokyr (1999), for instance, cites the sharp upward jump in patent statistics in Britain in the late 1750s, but argues that the role that patent laws and institutions had in raising the return to innovation is overrated (pp. 42-43)
} 
Although 1770 is the date often associated with the onset of the Industrial Revolution, it has been difficult to define the economic significance of what was going on in Britain. ${ }^{39}$ Europe between the late $18^{\text {th }}$ and the early $19^{\text {th }}$ century provides a useful point of comparison because there, we have documented changes that suggest a clear turning point. ${ }^{40}$ The fact that the degree of efficiency seen in Europe by the mid- $19^{\text {th }}$ century are similar to Britain in the late $18^{\text {th }}$ century suggests that important economy-wide changes had indeed occurred in Britain by around 1770 .

In Continental Europe, higher efficiency precedes the more definite (and dramatic) increases in economy-wide productivity that would appear later in the late $19^{\text {th }}$ and early $20^{\text {th }}$ century. Can efficient markets, then, be taken as a causal explanation of why the industrial revolution took place in Europe? While it's tempting to answer in the affirmative, we do not think that we can be sure about it. The fact that the large differences in efficiency emerge fairly late might suggest the causality between efficiency and growth is bi-directional. The main issue is that we can no longer place $1825-1849$ as being strictly before the onset of industrialization for Continental Europe because certain factors that were overtly important to European industrialization had diffused to the continent over the $18^{\text {th }}$ century. Already in the $18^{\text {th }}$ century, for instance, many of the early and key innovations of the British Industrial Revolution had found its way to France, Belgium, Germany, Hungary, and Sweden. ${ }^{41}$ In addition, British skills flowed to the continental in the form of human capital, and possibly other important sources of growth were spread to there as well. The transportation revolution and intensive railway construction is one example of a late $19^{\text {th }}$ century development that increased measured market

\footnotetext{
${ }^{39}$ The fact that we find evidence of a British lead in 1770-1794 is notable in light of recent evidence from Crafts and Harley (1992) suggesting growth rates growth in the late $18^{\text {th }}$ century were a modest $0.24 \%$ per year, a finding that has generated some debate about whether or not there might have been a significant break from the past before the mid- $19^{\text {th }}$ century. Growth rates above $1 \%$ per year in real output per capita appeared in Britain only by the $1830 \mathrm{~s}$.

${ }^{40}$ See also Persson (1999).

${ }^{41}$ Clark $(2002,5)$.
} 
efficiency, but these developments might not have been a source of growth so much as they were the result of it. Thus, the sense in which efficiency precedes growth is qualified by the fact that there were many cross-border flows of ideas and people between Britain and the continent, and the increase in efficiency in Continental Europe occurs only after the British Industrial Revolution. If market efficiency changes relatively quickly once the Industrial Revolution has started to take hold, our finding of high market efficiency would be to some extent a reflection, and not a cause of the Industrial Revolution.

\section{Conclusions}

The efficiency benefits that emerged from European institutions holds a prominent place in our understanding of economic growth, and it has also been offered as a leading explanation for why Europe succeeded to industrialize first. In this paper we examine the similarities and differences in markets in pre-industrial China and Europe from the $17^{\text {th }}$ to $19^{\text {th }}$ centuries. We use a range of methods to assess market efficiency in China and Europe in around 1770, to see whether we find one continent—specifically Europe—was clearly ahead.

In the period right before the Industrial Revolution spread to Continental Europe, market efficiency was not uniformly better than they were elsewhere in the world that did not industrialize. Over relatively short distances of $150 \mathrm{~km}$ or less, markets in continental Europe were more efficient. This edge over other advanced parts of the world however, is relatively small when we consider what occurs right after the onset of industrialization. In the early $19^{\text {th }}$ century, soon after the dates associated with the start of British industrialization, European markets become quickly and significantly more efficient than what had existed in prior centuries, and the level of efficiency was similar to Britain at the onset of its Industrial Revolution. Secure 
property rights, market-supporting institutions, and a well-functioning market economy may be necessary, but not sufficient conditions for an industrial revolution.

We find exceptionally well-performing markets in the times and places when we suspect that an industrial revolution was already under way and not before. Thus, the improvements in the degree of market efficiency in the $19^{\text {th }}$ century in Western Europe may be largely a reflection of the process of industrialization. This suggests not only that greater efficiency leads to growth, but that this process is endogenous as well (efficiency $<=>$ growth). If growth was a sudden process that influences market efficiency, this could also explain the sudden change.

Even allowing that all other conditions in Britain were just right for modern growth, the findings do not rule out that the possibility that a third factor was responsible for triggering improvements in growth, and that market efficiency is a response to these changes. Additional research is necessary to understand how institutional change occurs, and to explore how different institutional forms can be mapped into market outcomes. A particularly interesting direction for future work is to identify the factors that are important for growth, and are really not reflected in market efficiency, but were very different between Europe and other parts of the world. 


\section{DATA APPENDIX: SOURCES AND CHARACTERISTICS OF THE PRICE SERIES}

Goods: In general, these are prices for rice in China and for wheat in Europe. The exception is China's Hunan province, for which we have data on both rice and wheat. It has been used to confirm that the two grains do not fundamentally differ for the purposes of our analysis. Prices in China are for mid-quality rice; for Europe we do not have much specific information on quality, except for Bavaria (where sometimes red instead of white wheat was sold; the former is less expensive). The sources indicate that the quality of grains sold varied, and the price in Europe should be close to that for mid-quality wheat.

Price determination: For both China and Europe, these are market prices, with the exception of the Navy Victualling series for London (see below). In Europe, the prices come typically from mercuriales, which are official records of transactions at public markets.

Source and purpose of price records: In China, the data comes from price reports that prefects (the heads of prefectures, an administrative level above the county- and below the province-level) sent to the emperor in Beijing. Possibly, the empire-wide price reporting in China ensured a greater degree of comparability than in Europe. The main purpose of the recording of grain prices both in China and Europe was to prevent food crises.

Characteristics of the recorded prices: The price series vary in terms of temporal as well as spatial aggregation. Most prices are at a monthly frequency, except for annual data for ten French regions (Labrousse 1932; see below). The calculation of the monthly price varied, but the three most important methods are (1) average price of first market day of month, (2) average price of all transactions in a month, and (3) minimum and maximum during a month. The price averages are typically not quantityweighted; however, we have used prices and quantities available at a weekly frequency (e.g. for Cologne and Munich) to compute the correct average prices, and found that the difference is negligible. If the minimum and maximum price is available, we form the average price as $(\min +\max ) / 2$.

There is spatial aggregation to a varying extent. For example, the average price for the Paris series comes from two markets in the city, and the price for the Bretagne series covers all markets in the Bretagne. For Chinese prefectures, the average price is computed as the average of the lowest price in any market of the prefecture, plus the highest price in any market, divided by two. The area of some prefectures is considerably larger than a city. To explore the influence of that, we have alternatively used the lowest price in the prefecture: this tends to be the market in the prefectural capital, so there is little if any spatial aggregation. These results did not differ much from the main results that are reported. Similarly, we have explored the effects of spatial aggregation in Europe, and did not find major effects. Gonzalo (1993) discusses the extent to which time series properties - order of integration, cointegrationare preserved under temporal and cross-sectional (spatial) aggregation.

Selection of markets: The sample for China includes virtually all markets in the 10 provinces for which rice was the major grain, which suggests that sample selection plays essentially no role. For Europe, our data tends to be for markets of relatively big and relatively rich cities, because it was these cities that spent the resources needed for price collection. For instance, the 50 French markets in Drame et al. (1991), see below, are selected from some 900 markets as those where the greatest quantities were sold.

Missing data: There are substantial gaps in the sources; approximately $23 \%(15 \%)$ is missing in an average Chinese (European) series. We have used the TRAMO (Time Series Regression with ARIMA Noise, Missing Observations and Outliers) program to interpolate series for which there was not too much missing data (Gomez and Maravall 1997). This estimation of data does not critically affect our results. 


\section{Austria-Vienna}

Source: Pribram, Alfred Francis. Materialien zur Geschichte der Preise und Löhne in Österreich, Volume I. Vienna: Carl Überreuters Verlag, 1938.

Overall years: 1692 to 1914; frequency: monthly; method: quantity-weighted average of all market days. Quantity units: In "Wiener Metzen" (1692-1752), in "Niederösterreichen Landmetzen" (1752-1875), and in "100 Kilogram" (1875-1914). Conversion rates: 1 Wiener Metzen $=0.76$ Niederösterreiche

Landmetzen; 1 Niederösterreicher Landmetzen $=46.32$ Kilogram.

Monetary Units: "Kreuzer" (1692-1752); “Kreuzer Konventionsmünze" (1752-1812); "Kreuzer Wiener Währung” (1812-1858); “Kreuzer Österreichischer Währung” (1858-1897); "Heller Kronenwährung” (1898-1914). Conversion rates: 1 Gulden $=60$ Kreuzer $=60$ Kreuzer Konventionsmünze $=150$ Kreuzer Wiener Währung = 105 Kreuzer Wiener Währung = 210 Heller Kronenwährung.

Original source: "Marktprotokolle der Stadt Wien".

\section{Belgium-Brussels}

Source: For years 1568-1696, 1728-1795: Craeybeckx, J., "De Prijzen van Graan en van Brood te Brussel", in C. Verlinden (ed.) Dokumenten voor de Geschiedenis van Prijzen en Lonen in Vlaanderen en Brabant, Vol. I. Bruges: De Tempel, 1959.

Source: For years 1800-1889: Vandenbroeke, C., "Brusselse Merkuriale van Granen, Aardappelen, Hooi, Stro, Boter, Vlees, Koolzaad, Boskool en Steenkol", in C. Verlinden (ed.) Dokumenten voor de Geschiedenis van Prijzen en Lonen in Vlaanderen en Brabant, Vol. III. Bruges: De Tempel, 1972. Overall years: 1568-1889, with gaps; frequency: monthly; method: average from the month's first market day.

Quantity units: In "Bruxelles setier" (1568-1696, 1728-1795); in "100 liters" (1800-1871), and in "100 Kilograms" (1872-1889). Conversion rates: 1 Bruxelles setier $=48.76$ liters, and 79 kilograms $=100$ liters. Monetary units: In "Brabantse stuivers" (1568-1696, 1728-1795); in "French Francs" (1800-1817, 18331889), and in "Dutch Guilders" (1817-1832). Conversion rates: 20 Brabantse stuivers = 1 Dutch Guilder; and in 1816, 1 Dutch Guilder $=2.085$ French Francs, and in 1832, 1 Dutch Guilder $=2.117$ French Francs.

Original source: “Algemeen Rijksarchief te Brussel, Terminatieboeken”.

\section{Belgium-Brugge}

Source: Vanderpijpen, W., "Brugse Merkuriale van Granen, Brood, Aardappelen, Boter en Vlees (17961914)", in C. Verlinden (ed.), Dokumenten voor de Geschiedenis van Prijzen en Lonen in Vlaanderen en Brabant, Vol. IV. Bruges: De Tempel, 1973.

Overall years: 1796 to 1914, with few gaps; frequency: monthly; method: average from the month's first market day.

Quantity units: In "10 Kilograms" (1796-1802), in "100 liters" (1802-1890), and in "100 kilograms" (1892-1914). Conversion: 100 liter $=79$ kilograms.

Monetary units: In "French Francs" (1796-1817, 1833-1914), and in "Dutch Guilders" (1817-1832); see notes on Belgium-Brussels.

Original sources: "Rijksarchief Brugge (R.A.B.), Leiedepartement, 1076-1080 en 2831-2846" (for 17961812), and "Stadsarchief Brugge (S.A.B.), Gazette van Brugge" (for 1813-1914).

\section{Belgium-Aalst}

Source: Wyffels, A., "Prix du havot de froment à Alost", in C. Verlinden (ed.), Dokumenten voor de Geschiedenis van Prijzen en Lonen in Vlaanderen en Brabant, XV-XVIIICenturies, Bruges: De Tempel, 1959.

Overall years: 1729-1802, with major gaps before 1750; frequency: monthly; method: average, with variations.

Quantity units: In "havot" (i.e., per barrel). 
Monetary units: In "Gros de Flandre".

Original source: "Alost, Archives communales, $\mathrm{n}^{\circ} 261$ ".

\section{Belgium--Antwerp}

Source: Craeybeckx, J., "De Prijzen van granen en van brood te Antwerpen van 1608 tot 1817", in C. Verlinden (ed.) Dokumenten voor de Geschiedenis van Prijzen en Lonen in Vlaanderen en Brabant, Vol. I. Bruges: De Tempel, 1959.

Overall years: 1608 to 1817; frequency: monthly; method: average price on first market day of each month.

Quantity units: In Antwerp "Viertel".

Monetary units: In "Brabantse stuivers".

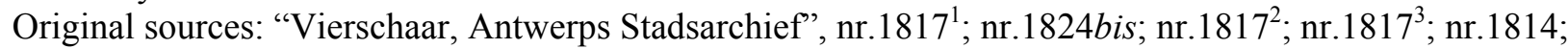
nr.1815; nr.1816.

\section{Luxemburg}

Source: Helin, E., Prix des Cereales a Luxembourg aux XVII et XVIII siecles, Universite de Louvain, 1966; part of Joseph Ruwet et al. (1966), Marché des céréales à Ruremonde, Luxembourg, Namur et Diest aux XVIIe et XVIIIe siècles, Leuven: Presse de l'Universite de Louvain, 1966.

Overall years: 1721 to 1794, with gaps; frequency: monthly; method: average of highest and lowest price on first market day of month, with some variation.

Quantity units: In "bichet", where 1 bichet (or setier) $=20.463$ liters.

Monetary units: In "Sous", where 1 Luxemburg Gulden is equal to 20 sous.

Original source: "Les Hallages de Luxembourg".

\section{China--121 Prefectural capitals}

Source: Data collection by Carol H. Shiue. These are rice prices; the sample covers virtually all prefectures of 10 provinces in China's Central/South-Central area; see Shiue (2002) as well as Roehner and Shiue (2000) for additional details.

Overall years: 1742 to 1795 , with gaps; frequency: monthly (collected and used: $2^{\text {nd }}$ and $8^{\text {th }}$ lunar month); method: highest and lowest price from all markets in a given prefecture. We take (highest price+lowest price) $/ 2$ as the average price in the prefectural capital.

Quantity units: In "shi", where $1 \mathrm{shi}=$ about 103 liters.

Monetary units: In "liang", which is a Chinese silver currency; it is also called "tael".

Original source: Gongzhong liangjiadan [Grain price lists in the palace archives]. Number One Historical Archives, Beijing.

\section{China--13 Prefectural capitals from Hunan province}

Source: Data collection by Peter Perdue; these are prices for rice and for wheat; see Perdue (1987) and Wong and Perdue (1992) for additional findings on Hunan province.

Overall years: 1736 to 1856, with gaps; frequency: monthly; method and units of account: see notes on China-121 Prefectural capitals.

Original source: Gongzhong liangjiadan [Grain price lists in the palace archives]. Number One Historical Archives, Beijing.

\section{England-London}

Source: Beveridge, William H. B. Prices and Wages in England from the Twelfth to the Nineteenth Century, Volume 1, (Price Tables: Mercantile Era; first edition 1939). London: Frank Cass \& Co. Ltd., 1965.

Overall years: 1683 to 1801, with gaps; frequency: monthly; method: average from prices for spot or future (usually up to one month) delivery. 
This series is conceptually different in that this series are not market, but British Navy procurement prices for grain. The Navy Victualling Board met daily to contract with dealers for the supply of provisions. There was a public announcement, after which the interested dealers were one-by-one asked to place their bid. The Navy tried to achieve the competitive market price outcome (for instance, indications of collusion among bidders resulted in the postponement of procurement activity). See pp.514-535 for details.

Quantity units: In "Quarters”. Monetary units: In "Shillings”.

\section{England-London and 40 Counties}

Source: The London Gazette.

Overall years: 1770 to 1794, with gaps; frequency: we employ data for the months January, March, July, and September (the source reports prices every week); method: average price of first week of month. Quantity units: In "Standard Winchester Bushel of 8 gallons" (1770-93), and in "Standard Winchester Quarter of 8 bushels" (1793-94).

Monetary units: In "Shillings" and "pence".

\section{France-Paris}

Source: Baulant, Micheline and Jean Meuvret. Prix des céréales extraits de la mercuriale de Paris. Paris: Ecole des Hautes Etudes, 1960.

Overall years: 1520 to 1698; frequency: monthly; method: average of maximum and minimum price on the first market day of month.

Quantity units: In "setier de Paris", where 1 setier $=156$ liter.

Monetary Units: In "Livres turnois".

Original source: "Mercuriale de Paris".

\section{France-Toulouse}

Source: Bertrand Roehner's preparation of figures in Frêche, Georges and Geneviève Frêche. Les prix des grains, des vins et des legumes à Toulouse. Paris: Presses Universitaires de France, 1967.

Overall years: 1486 to 1913; frequency: monthly; method: average of first market day of the month.

Quantity units: In "Hectoliter" (one hectoliter $=100$ liter).

Monetary units: In "French Francs and Centimes".

Conversions: The Frêche-Frêche data is in different quantity and monetary units for different periods; we have followed the conversion rates applied in Drame et al. (1991).

Original source: "Mercuriale de Toulouse".

France-Alençon, Amiens, Bourges, Bourgogne, Bretagne, Caen, Lyon, Riom, Rouen, Tours

Source: Labrousse, C.E. Esquisse du mouvement des prix et des revenus en France au 18 e siècle. Paris:

Paris C. 1932. See Roehner and Shiue (2000) for additional details.

Overall years: 1756 to 1790,1806 to 1900; frequency: annually; method: average. If the price is given for a region (e.g. Bretagne), we use the location of the central city of the region. Note that administrative boundaries were partly redefined during the French Revolution.

Quantity units: In "setier de Paris" (1756-1790), and in "Hectoliter" (1806-1900); conversion: one setier de Paris $=156$ liters.

Monetary units: In "100 livres" (1756-1790), and in "French Centimes"; conversion: 100 Centimes = 1 Francs $=1$ livre

\section{France-50 cities in French departements}

Source: Drame, Sylvie, Christian Gonfalone, Judith A. Miller, and Bertrand Roehner. Un Siècle de Commerce du Blé en France, 1825-1913. Paris: Economica, 1991.

Overall years: 1825 to 1913; frequency: every 15 days (1825-1903), and every month (1903-1913); method: quantity-weighted average from all market days in a given period (15 days, or a month). 
Quantity units: In "Hectoliters".

Monetary units: In "French Centimes", where 100 Centimes $=1$ French Francs.

Original source: Archives Nationales (Paris), $\mathrm{F}^{1{ }^{*}} 1779-2678$ and $\mathrm{F}^{1{ }^{*}} 2877-2984$.

\section{Germany-Cologne}

Source: Ebeling, Dietrich and Franz Irsigler, "Getreideumsatz, Getreide- und Brotpreise in Köln 13681797, Erster Teil: Getreideumsatz und Getreidepreise: Wochen-, Monats- und Jahrestabelle", in H. Stehkämper (ed.), Mitteilungen aus dem Stadtarchiv von Köln, Vol. 65-66. Köln-Wien: Böhlau-Verlag, 1976.

Overall years: 1368 to 1797, with gaps; frequency: monthly; method: average from 4 to 5 weekly prices. The source also lists weekly prices and quantities, which allows verifying that the difference between quantity-weighted and -unweighted monthly price is typically less than one percent.

Quantity units: In "Kölner Malter", which is approximately 150 liters or about 117 kilograms.

Monetary units: In "Albus"; conversions: 1 Albus $=12$ Heller, where the value of Albus to Gulden and Mark is 1 Gulden $=4$ Mark $=24$ Albus.

Original sources: "Die Fruchtpreisbücher von 1531-1674", "Die Bäckerbescheidbücher von 1658-1773”, and "Das Preise- und Umsatzverzeichnis von 1773-1797".

\section{Germany- Rostock, Schwerin, Wismar, Boizenburg, Parchim, and Grabow}

Source: Die Getreidepreise im Grossherzogthum Mecklenburg-Schwerin während des Zeitraums von 1771 bis 1870, Beiträge zur Statistik Mecklenburgs. Schwerin: Mecklenburg-Schwerin Statistisches Landesamt, 1873.

Overall years: 1771 to 1870, with gaps; frequency: monthly; method: average of mid-price of all market days in a month.

Quantity units: For Rostock and Schwerin in "Rostocker Scheffel" (RS); for Wismar in "Wismarer Scheffel" (WS); for Grabow and Parchim in "Maass" (M); and quantity units in Boizenburg are " $1 / 4$ Sack" $(1 / 4 \mathrm{~S})$. Conversions: $1 \mathrm{WS}=1.023331 \mathrm{RS}, 1 \mathrm{M}=1.436 \mathrm{RS}$, and $1 / 4 \mathrm{~S}=1.077 \mathrm{RS}$, where $1 \mathrm{RS}=$ 0.385371 Hectoliter.

Monetary units: In "Ganzen und Zehntel-Schillingen Courant" (i.e., in Courant, with decimals).

Original source: "Mecklenburgische Anzeigen" (a newspaper).

\section{Germany-Munich}

Source: Elsas, Moritz John. Umriss einer Geschichte der Preise und Löhne in Deutschland vom ausgehenden Mittelalter bis zum Beginn des neunzehnten Jahrhunderts. Leiden: A.W. Sijthoff, 1936. Overall years: 1690 to 1820, with gaps after 1779; frequency: monthly; method: average price of first market day of the month.

Quantity units: In "Scheffel", where 1 Scheffel = about 223 liters. Monetary units: In "Alten (schwarzen) Rechnungspfennigen".

Original source: "Schrannenzettel" of the city of Munich.

\section{Germany-Augsburg, Bamberg, Bayreuth, Erding, Kempten, Landshut, Lindau, Memmingen,} Munich, Nördlingen, Nürnberg, Regensburg, Straubing, Würzburg, Zweibrücken

Source: Seuffert, Georg Karl Leopold. Statistik des Getreide- und Viktualien-Handels im Königreiche Bayern mit Berücksichtigung des Auslandes. München: J.G. Weiss, 1857.

Overall years: 1815 to 1855 (Munich: 1790 to 1855); frequency: monthly; method: average price of all market days in a month. For Munich, the Seuffert (1857) source also contains weekly prices (for each Saturday). In principle, those are the prices listed in Elsas (1936); a comparison of the two sources essentially confirms that, also suggesting that these prices are highly accurate.

Quantity units: In "Bavarian Scheffel".

Monetary units: In "Gulden and Kreuzer"; 1 Gulden $=60$ Kreuzer; conversion to prices for Munich from Elsas (1936): 1 Kreuzer = 3.5 "Alte Rechnungspfennige". 


\section{Italy-Siena}

Source: Parente, Giuseppe. Prezzi e Mercato del Grano Siena 1546-1765. Florence: Carlo Cya, 1942. Overall years: 1546 to 1765, with gaps; frequency: monthly; method: average from all prices of the month.

Quantity units: In "Staio Senese"; 1 Staio Senese $=22.84$ liters.

Monetary units: In "Soldi"; this source gives conversion factors to compute constant prices. They are for the years 1542-1557: 0.23240; for the years 1558-1676: 0.22288; for the years 1677-1738: 0.21419; and for $1739-1766$, the conversion factor is 0.18912 . We have experimented with both current and constant prices, finding that the results are similar.

Original source: "Archivio degli Esecutori della Gabella", Archives of the State of Siena, documents \# 1283 to 1290.

\section{The Netherlands-Utrecht}

Source: Sillem, Jérome Alexandre. Tabellen van Marktprijzen van Granen te Utrecht in de Jaren 1393 tot 1644,Verhandelingen der Koninklijke Akademie van Wetenschappen te Amsterdam, Johannes Müller: Amsterdam, 1901; a supplement with the $18^{\text {th }}$ and $19^{\text {th }}$ century figures is published in Posthumus, N.W., Inquiry into the history of prices in Holland, E.J. Brill: Leiden, 1964.

Overall years: 1534-1644, 1760-1814; frequency: monthly; average of all prices for a given month. Quantity units: In "Modius"; 1 Modius = 88.93 kilograms.

Original source: "Rekeningen en weeklijsten der Domprossdij".

\section{The Netherlands-Nijmegen}

Source: Tijms, W. Historia Agriculturae. Groningen: Nederlands Agronomisch-Historisch Instituut, 1977.

Overall years: 1558-1916, with gaps; frequency: monthly; method: average price of the first market day of each month.

Quantity units: In "Malder" (1558-1822), and in "Hectoliter" (1824-1916); conversion: 1 Malder= 166.88 liter $=1.6688$ Hectoliter.

Monetary Units: In “Guldens” (Dutch Guilders).

\section{The Netherlands-Ruremonde}

Source: Ruwet, J., F. Ladrier, E. Helin, and L. van Buyten (1966), Marché des céréales à Ruremonde, Luxembourg, Namur et Diest aux XVIIe et XVIIIe siècles, Leuven: Presse de l'Universite de Louvain, 1966.

Overall years: 1599 to 1796; frequency: monthly; method: average of minimum and maximum of the first market day of each month.

Quantity units: In "Malder", where 1 Malder is about 170 liters (a range from 164.7 to 174.5 is given, p.17).

Monetary units: In "Stuivers", which in French are "patards". 


\section{REFERENCES}

Acemoglu, Daron, Simon Johnson, and James Robinson (2002), "The Rise of Europe: AtlanticTrade, Institutional Change and Economic Growth", NBER Working Paper \# 9378, Cambridge, MA, December.

Acemoglu, Daron, Simon Johnson, and James Robinson (2001), "The Colonial Origins of Comparative Development: An Empirical Investigation.” American Economic Review, 91: pp. 1369-1401.

Aghion, P., and P. Howitt (1998), Endogenous Growth Theory, Cambridge: MIT Press.

Allen, Robert C. (2002) "Involution, Revolution, or What? Agricultural Productivity, Income, and Chinese Economic Development." Mimeograph, Department of Economics, Nuffield College, Oxford, September.

Allen, Robert C. (2001), "Real Wages in Europe and Asia: A First Look at the Long-Term Patterns." Mimeograph, Department of Economics, Nuffield College, Oxford, August.

Anderson, J., and E. van Wincoop (2003), “Trade Costs”, working paper, Boston College.

Bairoch, Paul (1975), "The Main Trends in National Economic Disparities since the Industrial Revolution." In P. Bairoch and M. Levy-Leboyer, eds., Disparities in Economic Development since the Industrial Revolution. New York: St. Martin's Press.

Banerjee, Abhijit V. and Lakshmi Iyer (2002), "History, Institutions, and Economic Performance: The Legacy of Colonial Land Tenure Systems in India”, working paper, MIT.

Baten, Jörg (2000), "Climate, Grain Production and Nutritional Status in Southern Germany During the $18^{\text {th }}$ Century", mimeo, University of Munich.

Baulant, Micheline and Jean Meuvret (1960), Prix des céréales extraits de la mercuriale de Paris. Paris: Ecole des Hautes Etudes.

Beveridge, William H. B. (1965) Prices and Wages in England from the Twelfth to the Nineteenth Century, Volume 1. London: Frank Cass.

Braudel, Fernand (1992), The Structures of Everyday Life: The Limits of the Possible. Trans. Sian Reynolds. Berkeley: University of California Press.

Braudel Fernand and Frank C. Spooner (1967) "Prices in Europe from 1450 to 1750." In The Cambridge Economic History of Europe, Volume IV, New York: Cambridge University Press.

Chang, Chung-li (1962), The Income of the Chinese Gentry. Seattle: University of Washington 
Press, 1962.

Chaswick, Barry R. and Timothy Hatton (2003), "International Migration and the Integration of Labor Markets", in Globalization in Historical Perspective, edited by Michael D. Bordo, Alan M. Taylor, and Jeffrey G. Williamson.

Clark, Gregory (2002), “The Spread of the Industrial Revolution, 1860-2000.” Chapter 5 Mimeograph, Department of Economics, University of California at Davis.

Crafts, N. F. R. (1995), “Macroinventions, Economic Growth, and 'Industrial Revolution' in Britain and France," Economic History Review, 48: pp.591-598.

Crafts, N. F. R. (1994), “The Industrial Revolution.” In R. Floud and D. McCloskey (eds.), The Economic History of Britain Since 1700, Volume I: 1700-1860, New York: Cambridge University Press, 1994.

Crafts, N. F. R. (1985), British Economic Growth During the Industrial Revolution. New York: Oxford University Press.

Crafts, N. F. R., and C. K. Harley (1992), “Output Growth and the Industrial Revolution: A Restatement of the Crafts-Harley View”, Economic History Review 45: 703-730.

De Vries, Jan (1994), “The Industrial Revolution and the Industrious Revolution,” Journal of Economic History, 54: pp. 249-270.

Diamond, Jared (1997), Guns, Germs, and Steel: The Fate of Human Societies. New York: W.W. Norton \& Co.

Dickey, David and Wayne A. Fuller (1979), "Distribution of the Estimates for Autoregressive Time Series with a Unit Root." Journal of the American Statistical Association, 74: pp. 427-431.

Drame, Sylvie, Christian Gonfalone, Judith A. Miller, and Bertrand Roehner (1991), Un Siècle de Commerce du Blé en France, 1825-1913. Paris: Economica.

Durand, John (1960), "The Population Statistics of China, A.D. 2 - 1953," Population Studies 3, 2: pp. 209-56.

Ebeling, Dietrich and Franz Irsigler (1976), Getreideumsatz, Getreide- und Brotpreise in Köln 1368-1797, Volume 65. Cologne: Mitteilungen aus dem Stadtarchiv von Köln.

Elsas, Moritz John (1936), Umriss einer Geschichte der Preise und Löhne in Deutschland vom ausgehenden Mittelalter bis zum Beginn des neunzehnten Jahrhunderts. Leiden: A.W. Sijthoff.

Engel, C., and J. Rogers (1996), "How wide is the border?” American Economic Review 86: 
1112-1125.

Engerman, Stanley L., and Kenneth L. Sokoloff (2002), "Factor Endowments, Inequality, and Paths of Development Among New World Economies”, NBER Working Paper \# 9259, October 2002.

Engle, Robert F. and Clive W.J. Granger (1991), (eds.) Long-Run Economic Relationships, Readings in Cointegration. New York: Oxford University Press

Engle, Robert F. and Clive W.J. Granger (1987), "Co-integration and Error Correction: Representation, Estimation, and Testing." Econometrica, 55(2): 251-276.

Engle Robert F. and Byung Sam Yoo (1987), "Forecasting and Testing in Cointegrated Systems", Journal of Econometrics, 35(1): 143-59.

Frankel, Jeffrey A. and David Romer (1999), “Does Trade Cause Growth?” American Economic Review, 89(3): 379-99.

Frêche, Georges and Geneviève Frêche (1967), Les prix des grains des vins et des legumes à Toulouse. Paris: Presses Universitaires de France.

Fujita, M., P. Krugman, and A. Venables (1998), The Spatial Economy, MIT Press: Cambridge.

Glaser, Rüdiger (2001), Klimageschichte in Mitteleuropa seit dem Jahr 1000, Darmstadt.

Goldstone, Jack A. (2002), "Efflorences and Economic Growth in World History: Rethinking the "Rise of the West" and the Industrial Revolution," Journal of World History, 13(2): pp. 323-389.

Gomez, Victor and Agustin Maravall (1997), Program TRAMO (Time Series Regression with ARIMA Noise, Missing Observations, and Outliers) and SEATS (Signal Extraction in ARIMA Time Series). Instructions for the User. Madrid : Secretaria de Estado de Hacienda.

Gongzhong liangjiadan [Grain price lists in the palace archives]. Number One Historical Archives, Beijing.

Gonzalo, Jesus (1993), “Cointegration and Aggregation.” Richerche Economiche, 47(3): 281291.

Granger, Clive W.J. (1981), "Some properties of time series data and their use in econometric model specification.” Journal of Econometrics, 16: 121-30.

Hall, Robert and Charles Jones (1999), "Why Do Some Countries Produce So Much More Output per Worker than Others?" Quarterly Journal of Economics, 114(1): pp. 83-116. 
Harley, C. Knick (1999), "Reassessing the Industrial Revolution: A Macro View”, in The British Industrial Revolution. An Economic Perspective, Joel Mokry (ed.), $2^{\text {nd }}$ edition, Boulder: Westview Press.

Heckscher, E. (1916), "Växelkursens Grundval vid Pappersmyntfot”, Ekonomisk Tidskrift 18: 309-312.

Huang, Philip C. C. (2002), "Development or Involution in Eighteenth-Century Britain and China?" The Journal of Asian Studies, 61(2): 501-538.

Inkster, Ian (1991), Science and Technology in History: An Approach to Industrial Development. New Brunswick: Rutgers University Press.

Isham, Jonathan and Daniel Kaufmann (1999), "The Forgotten Rationale for Policy Reform: The Productivity of Investment Projects". Quarterly Journal of Economics, 114(1): pp. 14984.

Johansen, Soren (1988), "Statistical Analysis of Cointegration Vectors." Journal of Economic Dynamics and Control 12: 231-254.

Jones, Eric J. (2003), The European Miracle. Environments, economies and geopolitics in the history of Europe and Asia, $3^{\text {rd }}$ edition, Cambridge, UK: Cambridge University Press.

Jones, Charles (1995), “R\&D-based Models of Economic Growth”, Journal of Political Economy 103: 759-784.

Keller, Wolfgang and Carol. H. Shiue (2003), “The Origins of Spatial Interaction”, NBER Working Paper \# 10069, NBER, Cambridge, MA.

Labrousse, C. E. (1932), Esquisse du mouvement des prix et des revenus en France au 18 e siècle. Paris: Paris C.

Landes, David S. (1969), The Unbound Prometheus, Technological Change and Industrial Development in Western Europe from 1750 to the Present. London (England): Cambridge University Press.

Li, Bozhong (1998), Agricultural Development in Jiangnan, 1620-1850. New York: St. Martin's Press.

The London Gazette, London [England]: T.Neuman, Serial Publication Newspaper, on microfilm 1666-1800. San Antonio College Libraries, San Antonio, Texas.

MacKinnon, James G. (1991), “Critical Values for Cointegration Tests.” In Long-Run Economic Relationships, Readings in Cointegration, R. Engle and C.W.J. Granger, (eds)., New York: Oxford University Press. 
Maddala, G. S. and In-Moo Kim (1998), Unit Roots, Cointegration, and Structural Change. Cambridge: Cambridge University Press.

Maddison, Angus. (1989), The World Economy in the $20^{\text {th }}$ Century. Paris: OECD Publications and Information Center.

McCloskey, Donald and John Nash (1984), "Corn at Interest: The Extent and Cost of Grain Storage in Medieval England.” American Economic Review, 74(1): 174-187.

McEvedy, Colin and Richard Jones (1978), Atlas of World Population History, New York, Penguin.

McMillan, John (2002), Reinventing the Bazaar, A Natural History of Markets. New York: W.W. Norton.

Mecklenburg-Schwerin Statistisches Landesamt (1873), Beiträge zur Statistik Mecklenburgs. Schwerin: Grossherzogliches Statistisches Bureau.

Mitch, David (1999), "The Role of Education and Skill in the British Industrial Revolution," in The British Industrial Revolution: An Economic Perspective, $2^{\text {nd }}$ edition, edited by Joel Mokyr, Boulder: Westview Press.

Mokyr, Joel (1999), “Editor's Introduction: The New Economic History and the Industrial Revolution", in The British Industrial Revolution: An Economic Perspective, $2^{\text {nd }}$ edition, edited by Joel Mokyr, Boulder: Westview Press.

Mokyr, Joel (1990), The Lever of Riches. Technological Creativity and Economic Progress. New York: Oxford University Press.

North, Douglas C. (1981), Structure and Change in Economic History. New York: Norton.

North, Douglas C. and Robert Paul Thomas (1973), The Rise of the Western World, A New Economic History. New York: Cambridge University Press.

North, Douglas C. and Barry Weingast (1989), "Constitutions and Commitment: Evolution of Institutions Governing Public Choice in Seventeenth Century England." Journal of Economic History 51, pp. 23-46.

Olson, Mancur (1965), The Logic of Collective Action. Cambridge: Harvard University Press.

O'Rourke, K., and J. Williamson (2004), "From Malthus to Ohlin: Trade, Industrialization, and Distribution since 1500”, working paper, Trinity College Dublin and Harvard University.

O'Rourke, K., and J. Williamson (1999), Globalization and History: The Evolution of the $19^{\text {th }}$ Century Atlantic Economy. Cambridge: MIT Press. 
Parente, Giuseppe (1942), Prezzi e Mercato del Grano Siena (1546-1765). Florence: Carlo Cya.

Perdue, Peter (1987), Exhausting the Earth: State and Peasant in Hunan, 1500-1850. Chicago: Aldine Publishing.

Persson, Karl-Gunnar (1999), Grain Markets in Europe, 1500-1900, Integration and Deregulation. Cambridge: Cambridge University Press.

Pfister, Christian (2002), "The potential of documentary data for the reconstruction of past climates in Europe", ESF-Holivar workshop, Lammi, Finland, April 17-20 2002 , http://www.gsf.fi/esf_holivar/pfister.pdf, accessed January 2004.

Pomeranz, Kenneth (2000), The Great Divergence. Princeton: Princeton University Press.

Posthumus, N. W. (1964), Inquiry into the history of prices in Holland, Leiden: E.J. Brill.

Pribram, Alfred Francis (1938), Materialien zur Geschichte der Preise und Löhne in Österreich, Volume I. Vienna: Carl Überreuters Verlag.

Rodrik, Dani, Arvind Subramanian, and Francesco Trebbi (2002), "Institutions Rule: The Primacy of Institutions over Geography and Integration in Economic Development", NBER Working Paper \# 9305, November.

Roehner, Bertrand and Carol H. Shiue (2000), "Comparing the Correlation Length of Grain Markets in China and France." International Journal of Modern Physics C, 11(7): 13831410.

Ruwet, Joseph (1966), Marché des céréales à Ruremonde, Luxembourg, Namur et Diest aux XVIIe et XVIIIe siècles. Louvain: Bureau du recueil [de la] Bibiothèque de l'Université; Publications Universitaires de Louvain.

Sachs, Jeffrey (2003), “Institutions Don't Rule: Direct Effects of Geography on Per-Capita Income", NBER Working Paper \# 9490, February.

Seiffert, K. (1893), "Beitrag zur Geschichte der Zölle und indirekten Steuern in Bayern", Jahrbücher für Nationalökonomie und Geschichte, NF 5: 882-894.

Seuffert, Georg Karl Leopold (1857), Statistik des Getreide- und Viktualien-Handels im Königreiche Bayern mit Berücksichtigung des Auslandes. München: J.G. Weiss.

Shiue, Carol H. (2004a), "From Political Fragmentation towards the Nation State: Border Effects of the German Zollverein, 1815 to 1855 ", working paper, University of TexasAustin, February.

Shiue, Carol H. (2004b), "Local Granaries and Central Government Disaster Relief: Moral Hazard and Intergovernmental Finance in $18^{\text {th }}$ and $19^{\text {th }}$ Century China", Journal of 
Economic History, March.

Shiue, Carol. H. (2004c), “The Political Economy of Famine Relief”, working paper, University of Texas-Austin, January.

Shiue, Carol H. (2002), "Transport Costs and the Geography of Arbitrage in Eighteenth Century China." The American Economic Review, 92(5): 1406-1419.

Sillem, Jérome Alexandre (1901), Tabellen van Marktprijzen van Granen te Utrecht in de Jaren 1393 tot 1644, uit de rekeningen en weeklijsten der Domprossdij. Amsterdam: J. Müller, 1901.

Sokoloff, Kenneth L. and Stanley L. Engerman (2000), "Institutions, Factor Endowments, and Paths of Development in the New World", Journal of Economic Perspectives, 14(3): pp. 217-32.

Spooner, Frank C. (1961), "Régimes alimentaires d'autrefois: proportions et calculs en calories." Annales E.S.C., pp. 568-74.

State Meteorological Society (1981), Zhongguo jin wubai nien hanloa fenbu tuji [Collected maps of droughts and floods in China in the past five hundred years], Beijing, Ditu chuban she.

Taylor, Alan M. (2001), "Potential Pitfalls for the Purchasing-Power-Parity Puzzle? Sampling and Specification Biases in Mean-Reversion Tests of the Law of One Price", Econometrica 69: 473-498.

Tijms, W. (1977), Historia Agriculturae. Groningen: Nederlands Agronomisch-Historisch Instituut.

Verlinden, C. (1959), (ed.) Dokumenten voor de Geschiedenis van Prijzen en Lonen in Vlaanderen en Brabant, Vol. I. Bruges: De Tempel.

Verlinden, C. (1972), (ed.) Dokumenten voor de Geschiedenis van Prijzen en Lonen in Vlaanderen en Brabant, Vol. III. Bruges: De Tempel.

Verlinden, C. (1973), (ed.) Dokumenten voor de Geschiedenis van Prijzen en Lonen in Vlaanderen en Brabant, Vol. IV. Bruges: De Tempel.

Wang, Y. (1992), "Secular Trends of Rice Prices in the Yangzi Delta, 1638-1935", In Chinese History in Economic Perspective, T. Rawski and L. Li (eds.), Los Angeles, University of California Press.

Webb, Walter Prescott (1952), The Great Frontier. Boston, MA: Houghton Mifflin.

Weber, Max (1993), The Protestant Ethic and the Spirit of Capitalism. London: Routledge, originally published 1905 . 
Wilkinson, E. (1969), “The Nature of Chinese Grain Price Quotations, 1600-1900”, Transactions of the International Conference of Orientalists in Japan/Kokusai Toho Gakusha Kaigi Kiyo, Vol. 14: 54-65.

Will, Pierre-Etienne and R. Bin Wong (1991), Nourish the People. Ann Arbor: University of Michigan Press.

Wong, R. Bin and Peter Perdue (1992), "Grain Markets and Food Supplies in $18^{\text {th }}$ Century Hunan." In Chinese History in Economic Perspective, T. Rawski and L. Li (eds.), Los Angeles, University of California Press.

Wrigley, E.A. (1988), Continuity, Chance and Change: The Character of the Industrial Revolution in England. New York: Cambridge University Press. 
Table 1. Data Sources

\begin{tabular}{|c|c|c|c|c|c|c|c|c|}
\hline $\mathrm{I}$ & II & III & IV & $\mathrm{V}$ & $\mathrm{VI}$ & VII & VIII & IX \\
\hline Country & Location & Source & Frequency & Years & Method & $\begin{array}{l}\text { Max/Min } \\
\text { Obs. }\end{array}$ & $\begin{array}{c}\text { Spatial } \\
\text { Aggregate }\end{array}$ & $\begin{array}{l}\text { Quantity } \\
\text { Weighted }\end{array}$ \\
\hline Austria & Vienna & Pribram (1938) & Monthly & $1692-1914$ & Average & no & no & yes \\
\hline \multirow[t]{7}{*}{ Belgium } & Brussels & Verlinden (1959) & Monthly & 1568-1696 & First day & no & no & no \\
\hline & & Verlinden (1972) & Monthly & $1728-95,1800-89$ & First day & no & no & no \\
\hline & Bruges & Verlinden (1973) & Monthly & $1796-1914$ & First day & no & no & no \\
\hline & & Verlinden $(1959,1973$ & Monthly & $1564-1604$ & Avg./1st day & no & no & no \\
\hline & Diksmuide & Verlinden (1959) & Monthly & $1482-1615$ & Average & no & no & no \\
\hline & Aalst & Verlinden (1959) & Monthly & $1750-1802$ & Average & no & no & no \\
\hline & Antwerp & Verlinden (1959) & Monthly & $1608-1817$ & First day & no & no & no \\
\hline \multirow[t]{12}{*}{ China } & Hunan province (13 pref.) ${ }^{*}$ & see Perdue (1987) & Monthly & $1738-1858$ & First day & yes & yes & no \\
\hline & 121 Prefectures & see Shiue (2002) & Monthly & $1742-1795$ & First day & yes & yes & no \\
\hline & Anhwei province (13 pref.) & & " & & & & & \\
\hline & Fujian province (12 pref.) & & " & & & & & \\
\hline & Guangdong province (13 pref.) & & $"$ & & & & & \\
\hline & Guangxi province (13 pref.) & & $"$ & & & & & \\
\hline & Guizhou province (12 pref.) & & $"$ & & & & & \\
\hline & Hubei province (10 pref.) & & " & & & & & \\
\hline & Hunan province (13 pref.) & & $"$ & & & & & \\
\hline & Jiangsu province (10 pref.) & & $"$ & & & & & \\
\hline & Jiangxi province (14 pref.) & & $"$ & & & & & \\
\hline & Zhejiang province (11 pref.) & & $"$ & & & & & \\
\hline \multirow[t]{2}{*}{ England } & London & Beveridge (1965) & Monthly & $1683-1801$ & Average & no & no & no \\
\hline & London and 40 Counties & London Gazette & Weekly & $1770-1794$ & Weekly avg. & no & yes & no \\
\hline \multirow[t]{4}{*}{ France } & Toulouse & Freche (1967) & Monthly & $1486-1913$ & First day & no & no & in part \\
\hline & Paris & Baulant (1960) & Monthly & $1520-1698$ & First day & yes & no & no \\
\hline & 10 Generalite (Regions) & Labrousse (1932) & Annual & $1756-90,1806-1900$ & Average & no & in part & in part \\
\hline & 50 Cities, 48 Departments & Drame (1991) & Biweekly & $1825-1903$ & First day & no & yes & yes \\
\hline \multirow[t]{4}{*}{ Germany } & Cologne & Ebeling (1976) & Monthly & $1531-1797$ & Average & no & no & no \\
\hline & 6 Cities Mecklenburg-Schwerin & Mecklenburg (1873) & Monthly & $1770-1870$ & Average & no & no & no \\
\hline & 14 Cities in Bavaria & Seuffert (1857) & Monthly & $1815-1855$ & Average & no & no & no \\
\hline & Munich & Elsas (1936) & Monthly & $1790-1855$ & First day & no & no & no \\
\hline Italy & Siena & Parenti (1942) & Monthly & $1546-1765$ & Average & no & no & no \\
\hline Luxembourg & Luxembourg & Ruwet (1966) & Monthly & $1722-1795$ & Variable & in part & no & no \\
\hline \multirow{4}{*}{ Netherlands } & Nijmegen & Tijms (1977) & Monthly & $1558-1916$ & First day & start 1814 & no & no \\
\hline & Utrecht & Sillem (1901) & Monthly & $1534-1647$ & Average & no & no & no \\
\hline & & Posthumus (1964) & Monthly & $1774-1814$ & Average & no & no & no \\
\hline & Ruremonde & Ruwet (1966) & Monthly & $1599-1796$ & First day & yes & no & in part \\
\hline
\end{tabular}

Notes:

Column VI indicates whether the prices were calculated from the first market day of the month or with a temporal averaging method.

Column VII indicates if the data records a range of prices, ie, typically the minimum and maximum prices observed.

Column VIII notes if spatial aggregation is involved; these cases are only relevant for regions larger than a city market, such as departments or prefectures.

Column IX indicates if price averages have been quantity-weighted in the original source.

*Hunan series of monthly prices for both rice and wheat. 
Table 2a. Price Correlations in China and Europe 1742-1794 in 25 year periods

\begin{tabular}{|c|c|c|c|c|c|c|c|c|c|c|c|c|}
\hline Country & Sample & $\mathrm{N}^{*}$ & $\begin{array}{c}\text { Dist range } \\
\text { in } \mathrm{km}\end{array}$ & $\mathrm{n}^{* *}$ & \multicolumn{2}{|c|}{$\begin{array}{l}1742-1766 \\
\text { Mean stdev }\end{array}$} & \multicolumn{2}{|c|}{$\begin{array}{l}1756-1780 \\
\text { Mean stdev }\end{array}$} & \multicolumn{2}{|c|}{$\begin{array}{l}1766-1790 \\
\text { Mean stdev }\end{array}$} & \multicolumn{2}{|c|}{$\begin{array}{l}1770-1794 \\
\text { Mean stdev }\end{array}$} \\
\hline \multirow[t]{21}{*}{ China } & Yangzi Delta & 9 & $<150$ & 25 & 0.76 & 0.15 & 0.80 & 0.10 & 0.84 & 0.05 & 0.83 & 0.07 \\
\hline & & 9 & $150-300$ & 11 & 0.73 & 0.13 & 0.74 & 0.08 & 0.81 & 0.04 & 0.81 & 0.06 \\
\hline & Yangzi D. expanded & 26 & $<150$ & 85 & 0.77 & 0.12 & 0.75 & 0.11 & 0.80 & 0.09 & 0.78 & 0.10 \\
\hline & & 26 & $150-300$ & 138 & 0.67 & 0.15 & 0.68 & 0.11 & 0.71 & 0.11 & 0.70 & 0.12 \\
\hline & & 26 & $300-450$ & 76 & 0.54 & 0.20 & 0.56 & 0.16 & 0.65 & 0.09 & 0.66 & 0.11 \\
\hline & & 26 & $450-600$ & 26 & 0.44 & 0.17 & 0.53 & 0.17 & 0.59 & 0.09 & 0.67 & 0.13 \\
\hline & Provincial Capitals & 10 & $<150$ & 0 & --- & & --- & & --- & & --- & \\
\hline & & 10 & $150-300$ & 8 & 0.58 & 0.11 & 0.49 & 0.24 & 0.64 & 0.25 & 0.59 & 0.24 \\
\hline & & 10 & $300-450$ & 7 & 0.53 & 0.20 & 0.50 & 0.32 & 0.61 & 0.33 & 0.61 & 0.36 \\
\hline & & 10 & $450-600$ & 8 & 0.53 & 0.07 & 0.26 & 0.18 & 0.38 & 0.30 & 0.38 & 0.31 \\
\hline & & 10 & $600-750$ & 6 & 0.32 & 0.23 & 0.29 & 0.27 & 0.29 & 0.41 & 0.31 & 0.35 \\
\hline & & 10 & $750-900$ & 6 & 0.38 & 0.17 & 0.14 & 0.22 & 0.11 & 0.30 & 0.15 & 0.34 \\
\hline & & 10 & $900-1050$ & 2 & 0.35 & 0.17 & 0.03 & 0.17 & -0.10 & 0.08 & -0.14 & 0.15 \\
\hline & & 10 & $>1050$ & 8 & 0.23 & 0.14 & 0.13 & 0.24 & 0.10 & 0.25 & 0.08 & 0.22 \\
\hline & Yangzi River & 34 & $<150$ & 68 & 0.78 & 0.12 & 0.77 & 0.11 & 0.82 & 0.07 & 0.81 & 0.09 \\
\hline & & 34 & $150-300$ & 124 & 0.68 & 0.14 & 0.69 & 0.12 & 0.75 & 0.09 & 0.74 & 0.12 \\
\hline & & 34 & $300-450$ & 146 & 0.58 & 0.16 & 0.60 & 0.13 & 0.68 & 0.10 & 0.68 & 0.10 \\
\hline & & 34 & $450-600$ & 120 & 0.54 & 0.16 & 0.55 & 0.13 & 0.65 & 0.09 & 0.66 & 0.09 \\
\hline & & 34 & $600-750$ & 57 & 0.51 & 0.15 & 0.45 & 0.14 & 0.64 & 0.12 & 0.64 & 0.10 \\
\hline & & 34 & $750-900$ & 34 & 0.50 & 0.10 & 0.42 & 0.11 & 0.61 & 0.11 & 0.61 & 0.11 \\
\hline & & 34 & $900-1050$ & 12 & 0.42 & 0.13 & 0.31 & 0.11 & 0.56 & 0.08 & 0.57 & 0.08 \\
\hline \multirow[t]{4}{*}{ England } & London +40 counties & 41 & $<150$ & 328 & --- & & --- & & --- & & 0.87 & 0.06 \\
\hline & & 41 & $150-300$ & 343 & --- & & --- & & --- & & 0.77 & 0.06 \\
\hline & & 41 & $300-450$ & 133 & --- & & --- & & --- & & 0.71 & 0.07 \\
\hline & & 41 & $450-600$ & 16 & --- & & --- & & --- & & 0.71 & 0.08 \\
\hline \multirow[t]{4}{*}{ France } & Central France & 10 & $<150$ & 10 & --- & & 0.88 & 0.04 & 0.80 & 0.09 & 0.80 & 0.09 \\
\hline & & 10 & $150-300$ & 13 & --- & & 0.82 & 0.07 & 0.70 & 0.15 & 0.74 & 0.14 \\
\hline & & 10 & $300-450$ & 14 & --- & & 0.74 & 0.07 & 0.58 & 0.09 & 0.65 & 0.09 \\
\hline & & 10 & $450-600$ & 8 & --- & & 0.74 & 0.07 & 0.55 & 0.08 & 0.63 & 0.08 \\
\hline \multirow[t]{8}{*}{ Europe } & $\{$ Mecklenburg(3), & 15 & $<150$ & 17 & --- & & --- & & --- & & 0.83 & 0.09 \\
\hline & Belgium(3),London, & 15 & $150-300$ & 15 & --- & & --- & & --- & & 0.65 & 0.15 \\
\hline & France(1),Austria(1), & 15 & $300-450$ & 13 & --- & & --- & & --- & & 0.55 & 0.21 \\
\hline & Germany(2), & 15 & $450-600$ & 20 & --- & & --- & & --- & & 0.53 & 0.17 \\
\hline & Luxembourg, & 15 & $600-750$ & 14 & --- & & --- & & --- & & 0.39 & 0.15 \\
\hline & Netherlands(2), & 15 & $750-900$ & 11 & --- & & --- & & --- & & 0.33 & 0.16 \\
\hline & Ruremonde\}. & 15 & $900-1050$ & 10 & --- & & --- & & --- & & 0.30 & 0.09 \\
\hline & & 15 & $>1050$ & 5 & --- & & --- & & --- & & 0.30 & 0.10 \\
\hline
\end{tabular}


Table 2b. Price Correlation in Europe 1692-1716 and 1806-1855 in 25 year periods.

\begin{tabular}{|c|c|c|c|c|c|c|c|c|c|c|c|c|c|c|}
\hline Country & Sample & $\mathrm{N}^{*}$ & $\begin{array}{c}\text { Dist range } \\
\text { in } \mathrm{km}\end{array}$ & $\mathrm{n}^{* *}$ & \multicolumn{2}{|c|}{$1692-1716$} & \multicolumn{2}{|c|}{$1806-1830$} & $\begin{array}{l}1815-1 \\
\text { Mean }\end{array}$ & $\begin{array}{l}834 \\
\text { stdev }\end{array}$ & $\begin{array}{l}1825-1 \\
\text { Mean }\end{array}$ & $\begin{array}{l}849 \\
\text { stdev }\end{array}$ & \multicolumn{2}{|c|}{$\begin{array}{l}\text { 1831-1855 } \\
\text { Mean stdev }\end{array}$} \\
\hline \multirow[t]{10}{*}{ France } & Central France & 10 & $<150$ & 10 & --- & & 0.96 & 0.02 & 0.97 & 0.02 & 0.96 & 0.02 & 0.98 & 0.01 \\
\hline & & 10 & $150-300$ & 13 & --- & & 0.93 & 0.03 & 0.95 & 0.02 & 0.94 & 0.03 & 0.97 & 0.01 \\
\hline & & 10 & $300-450$ & 14 & --- & & 0.90 & 0.02 & 0.91 & 0.03 & 0.89 & 0.04 & 0.95 & 0.02 \\
\hline & & 10 & $>450$ & 8 & --- & & 0.87 & 0.04 & 0.88 & 0.03 & 0.84 & 0.03 & 0.94 & 0.01 \\
\hline & France & 51 & $<150$ & 140 & & & --- & & --- & & 0.91 & 0.07 & 0.94 & 0.05 \\
\hline & & 51 & $150-300$ & 344 & --- & & --- & & --- & & 0.87 & 0.06 & 0.91 & 0.05 \\
\hline & & 51 & $300-450$ & 321 & --- & & --- & & --- & & 0.82 & 0.07 & 0.88 & 0.05 \\
\hline & & 51 & $450-600$ & 276 & --- & & --- & & --- & & 0.75 & 0.08 & 0.83 & 0.06 \\
\hline & & 51 & $600-750$ & 155 & --- & & --- & & --- & & 0.71 & 0.08 & 0.81 & 0.06 \\
\hline & & 51 & $<750$ & 39 & --- & & --- & & --- & & 0.70 & 0.05 & 0.79 & 0.03 \\
\hline \multirow[t]{7}{*}{ Germany } & Bavaria & 13 & $<150$ & 37 & --- & & --- & & 0.98 & 0.01 & 0.97 & 0.02 & 0.98 & 0.02 \\
\hline & & 13 & $150-300$ & 41 & --- & & --- & & 0.96 & 0.02 & 0.93 & 0.03 & 0.95 & 0.02 \\
\hline & Bavaria \& & 20 & $<150$ & 65 & --- & & --- & & 0.97 & 0.02 & 0.96 & 0.02 & 0.97 & 0.02 \\
\hline & Mecklenburg & 20 & $150-300$ & 40 & --- & & --- & & 0.95 & 0.02 & 0.93 & 0.03 & 0.95 & 0.02 \\
\hline & & 20 & $300-450$ & 18 & --- & & --- & & 0.81 & 0.05 & 0.78 & 0.06 & 0.84 & 0.05 \\
\hline & & 20 & $450-600$ & 42 & --- & & --- & & 0.76 & 0.04 & 0.73 & 0.04 & 0.78 & 0.04 \\
\hline & & 20 & $600-750$ & 25 & --- & & --- & & 0.74 & 0.04 & 0.71 & 0.03 & 0.75 & 0.05 \\
\hline \multirow[t]{8}{*}{ Europe } & \{Belgium(2), & 15 & $<150$ & 8 & --- & & --- & & --- & & 0.97 & 0.01 & 0.96 & 0.03 \\
\hline & France(4), & 15 & $150-300$ & 9 & --- & & --- & & --- & & 0.90 & 0.06 & 0.94 & 0.03 \\
\hline & Germany(4), & 15 & $300-450$ & 9 & --- & & --- & & --- & & 0.78 & 0.10 & 0.85 & 0.07 \\
\hline & Mecklenburg(3) & 15 & $450-600$ & 22 & --- & & --- & & --- & & 0.77 & 0.08 & 0.83 & 0.06 \\
\hline & Austria(1), & 15 & $600-750$ & 25 & --- & & --- & & --- & & 0.72 & 0.09 & 0.78 & 0.08 \\
\hline & Netherlands(1)\} & 15 & $750-900$ & 12 & --- & & --- & & --- & & 0.69 & 0.05 & 0.74 & 0.02 \\
\hline & & 15 & $900-1050$ & 10 & --- & & --- & & --- & & 0.69 & 0.05 & 0.72 & 0.04 \\
\hline & & 15 & $1050-1200$ & 10 & --- & & --- & & --- & & 0.54 & 0.11 & 0.57 & 0.12 \\
\hline \multirow[t]{8}{*}{ Europe } & \{Belgium(1), & 9 & $<150$ & 4 & 0.89 & 0.03 & --- & & --- & & --- & & --- & \\
\hline & France(1), & 9 & $150-300$ & 2 & 0.88 & 0.06 & --- & & --- & & --- & & --- & \\
\hline & London,Italy(1), & 9 & $300-450$ & 4 & 0.55 & 0.27 & --- & & --- & & --- & & --- & \\
\hline & Austria(1), & 9 & $450-600$ & 5 & 0.29 & 0.24 & --- & & --- & & --- & & --- & \\
\hline & Germany(2), & 9 & $600-750$ & 3 & 0.43 & 0.08 & --- & & --- & & --- & & --- & \\
\hline & Netherlands(2)\} & 9 & $750-900$ & 5 & 0.46 & 0.09 & --- & & --- & & --- & & --- & \\
\hline & & 9 & $900-1050$ & 10 & 0.4 & 0.16 & --- & & --- & & --- & & --- & \\
\hline & & 9 & $1050-1200$ & 3 & 0.36 & 0.09 & --- & & --- & & --- & & --- & \\
\hline
\end{tabular}

* Gives the number of markets in a sample

** Gives the number of bilateral relations in a specific distance range 
Table 3. Distance slope coefficients in China and Europe, 1742-1855 in 25 year periods.

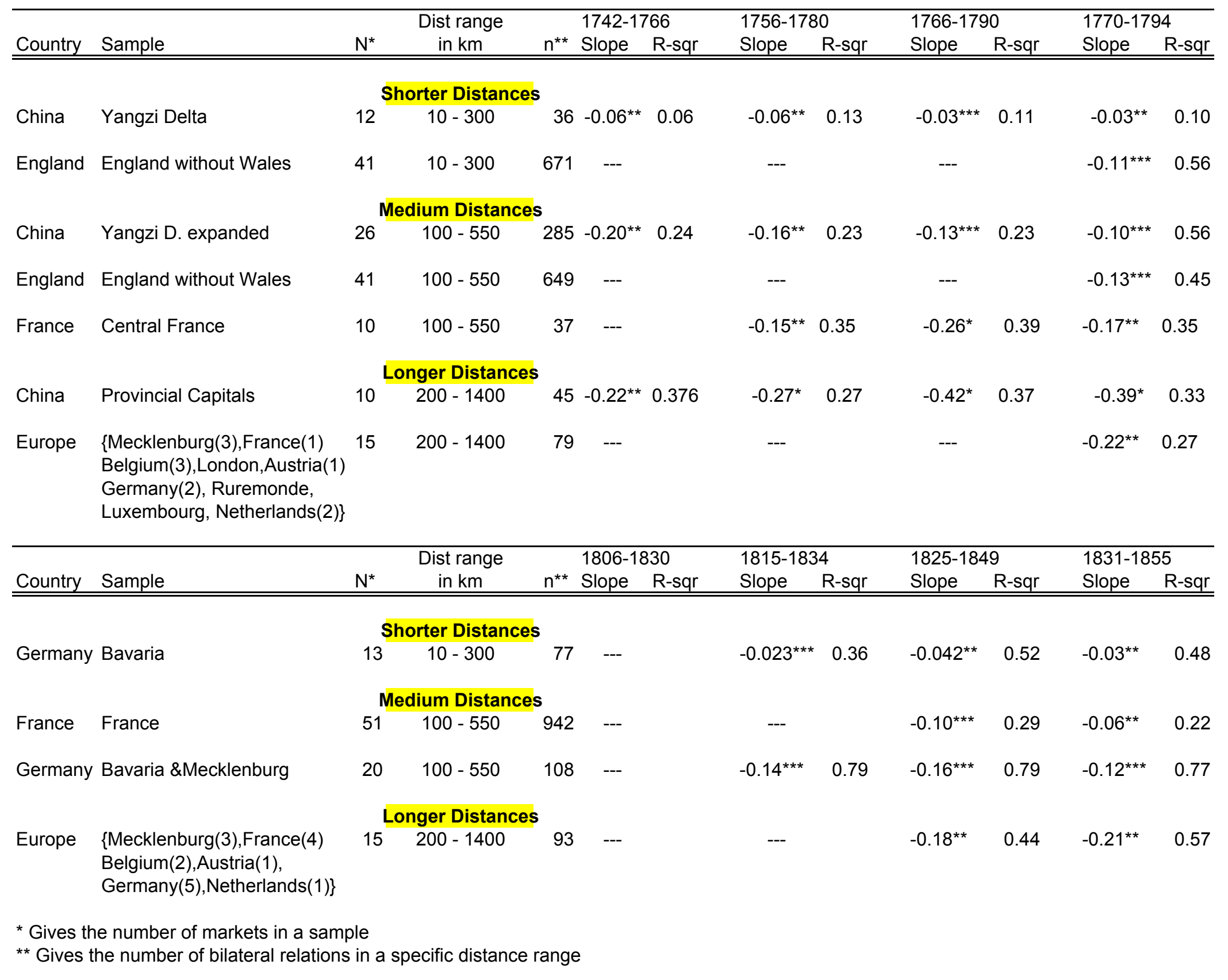


Table 4: Engle-Granger Cointegration Results

\begin{tabular}{lcccccc}
\hline & \multicolumn{3}{c}{ Europe 15 markets } & \multicolumn{2}{c}{ England 40 county markets + London } \\
$\begin{array}{l}\text { Distance class } \\
(\mathrm{km})\end{array}$ & $\begin{array}{c}\text { Mean ADF } \\
\mathrm{t} \text {-stat }\end{array}$ & S.e. of Mean & $\begin{array}{c}\text { Median ADF } \\
\mathrm{t} \text {-stat }\end{array}$ & $\begin{array}{c}\text { Mean ADF } \\
\text { t-stat }^{*}\end{array}$ & $\begin{array}{c}\text { S.e. of Mean } \\
\text { t-stat }\end{array}$ \\
\hline \hline $0<\mathrm{x}<150$ & -4.450 & 0.131 & -4.382 & -4.582 & 0.031 & -4.577 \\
$150<\mathrm{x}<300$ & -3.807 & 0.113 & -3.757 & -4.450 & 0.031 & -4.451 \\
$300<\mathrm{x}<450$ & -3.757 & 0.145 & -3.766 & -4.382 & 0.058 & -4.392 \\
$450<\mathrm{x}<600$ & -3.493 & 0.103 & -3.375 & -4.464 & 0.186 & -4.254 \\
$600<\mathrm{x}<750$ & -3.163 & 0.190 & -2.853 & & & \\
$750<\mathrm{x}<900$ & -3.604 & 0.186 & -3.533 & & & \\
$900<\mathrm{x}$ & -3.582 & 0.169 & -3.498 & & & \\
\hline
\end{tabular}

${ }^{*}$ As shown in Figure 9 
Figure 1. Data Availability, selected locations.

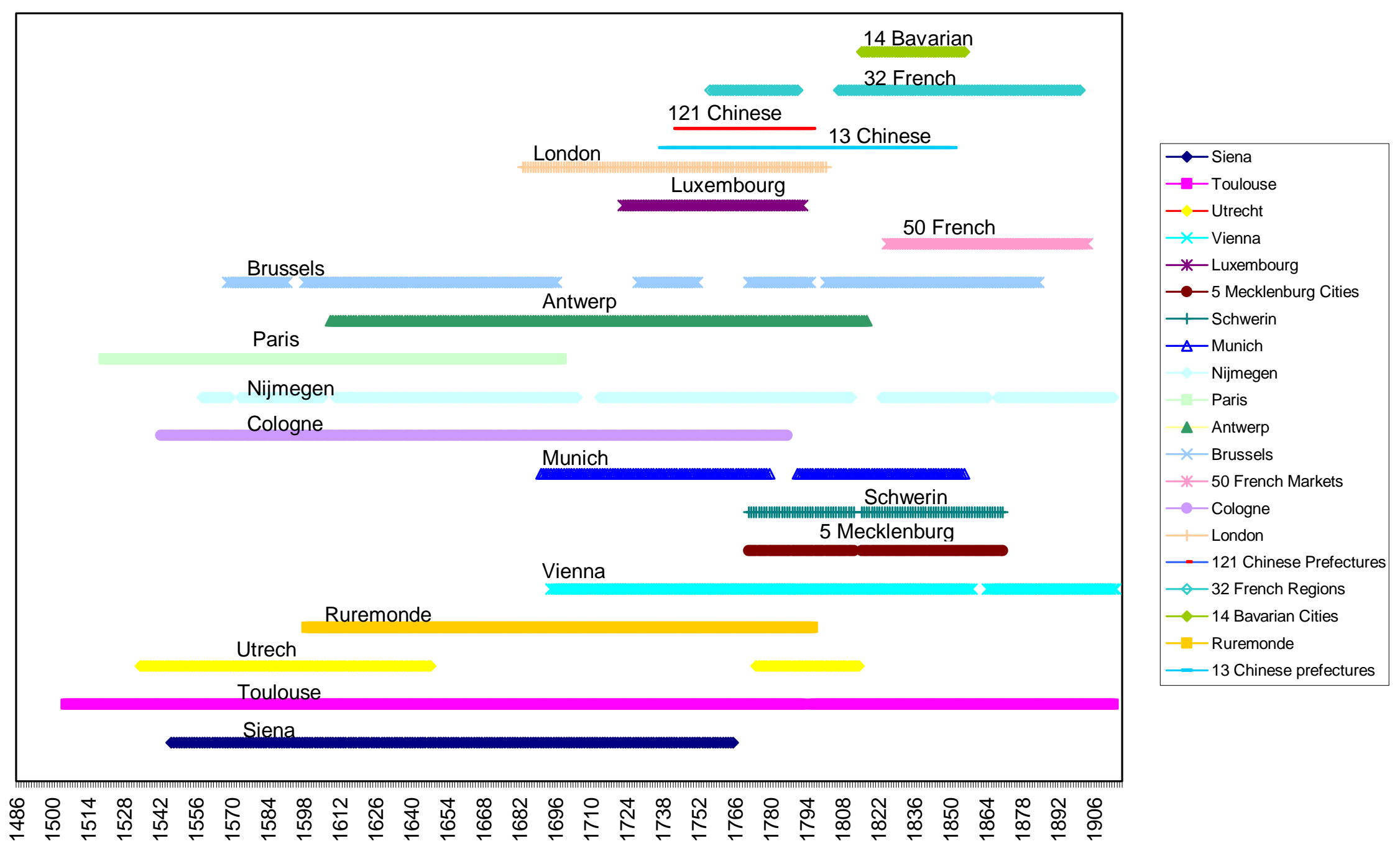


Figure 2. China and Europe, selected markets, 1770-1794

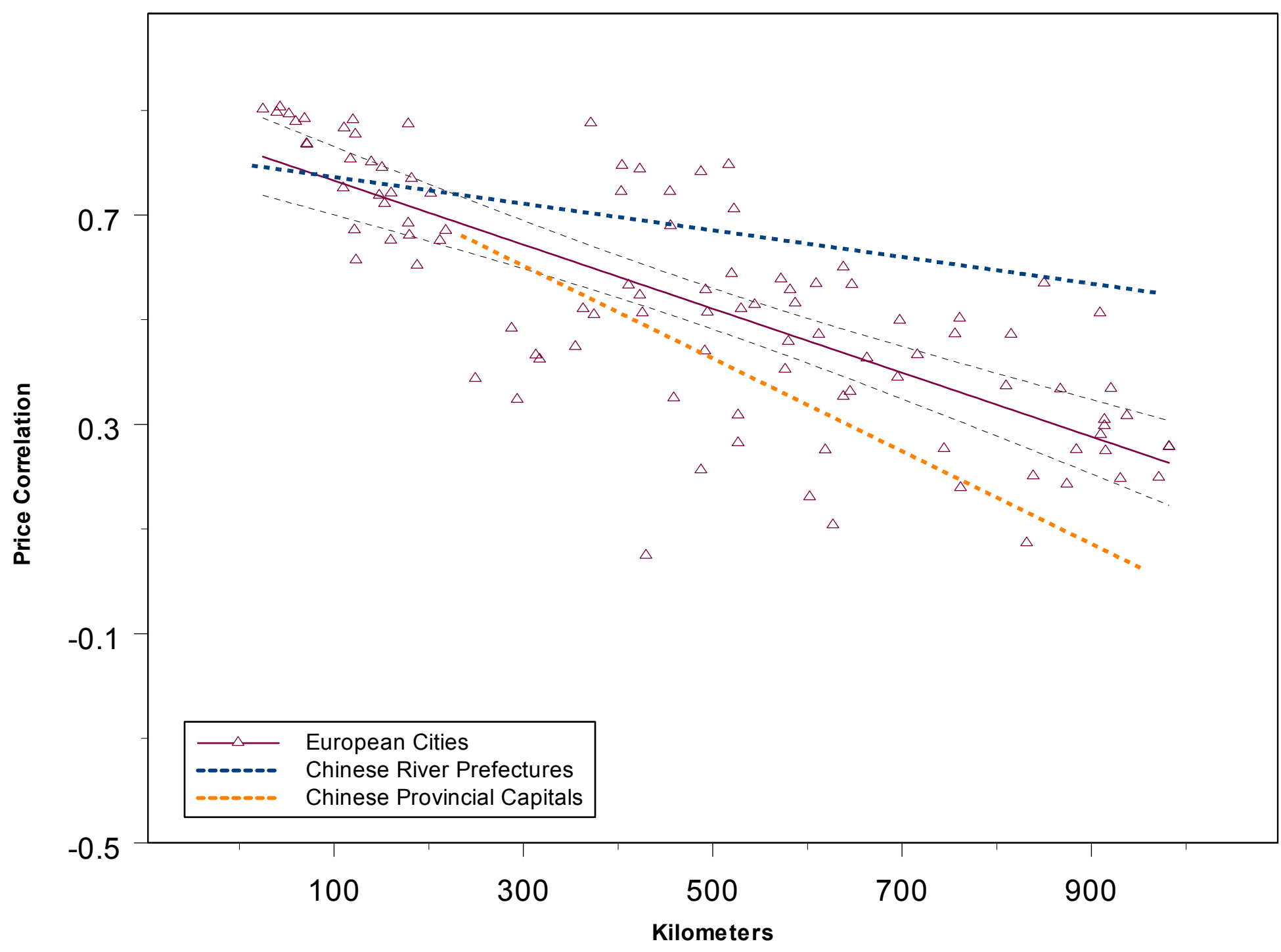


Figure 3. European locations, 17 th and 18th century samples compared

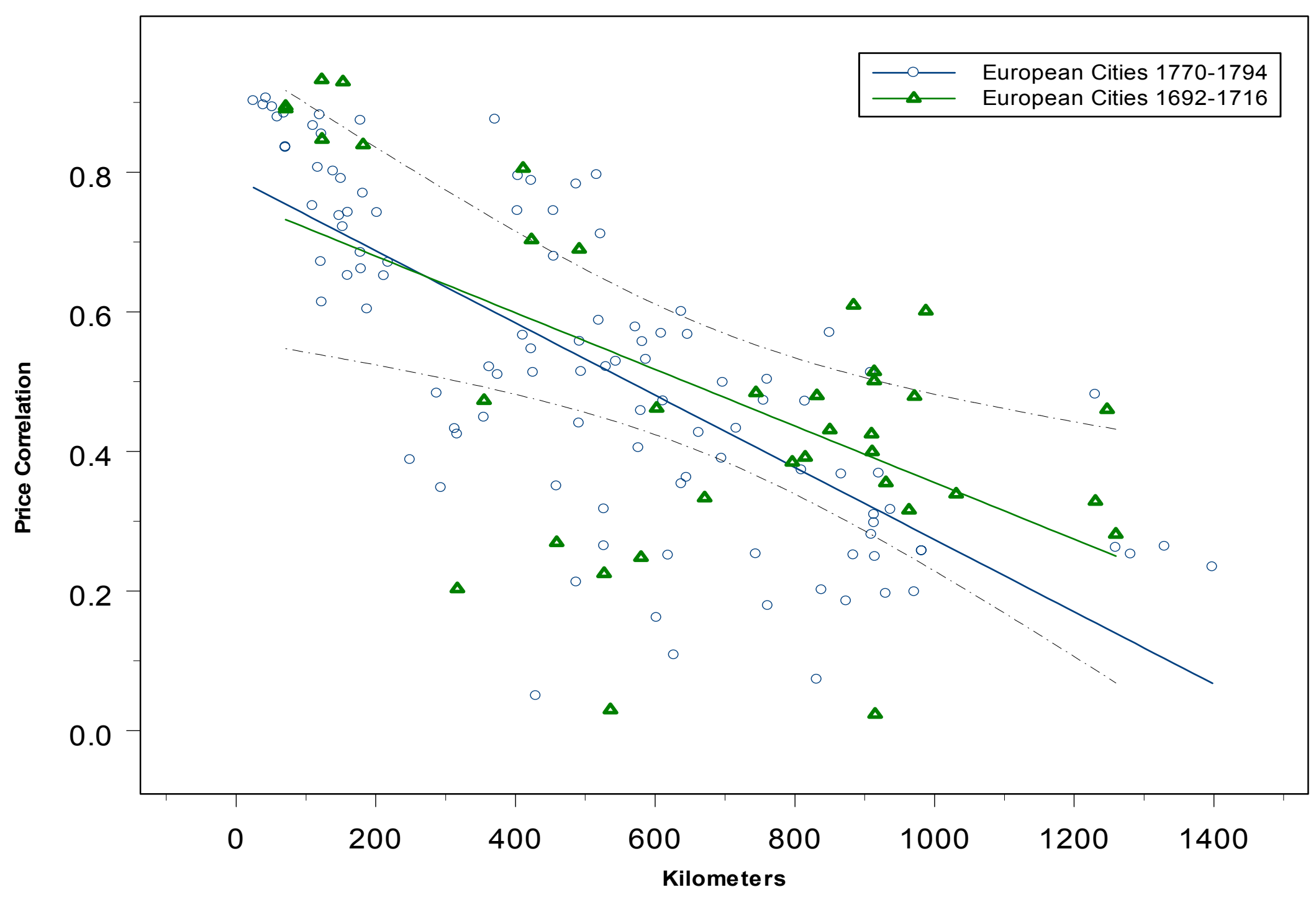


Figure 4. China and Europe, selected markets over 18th and 19th centuries

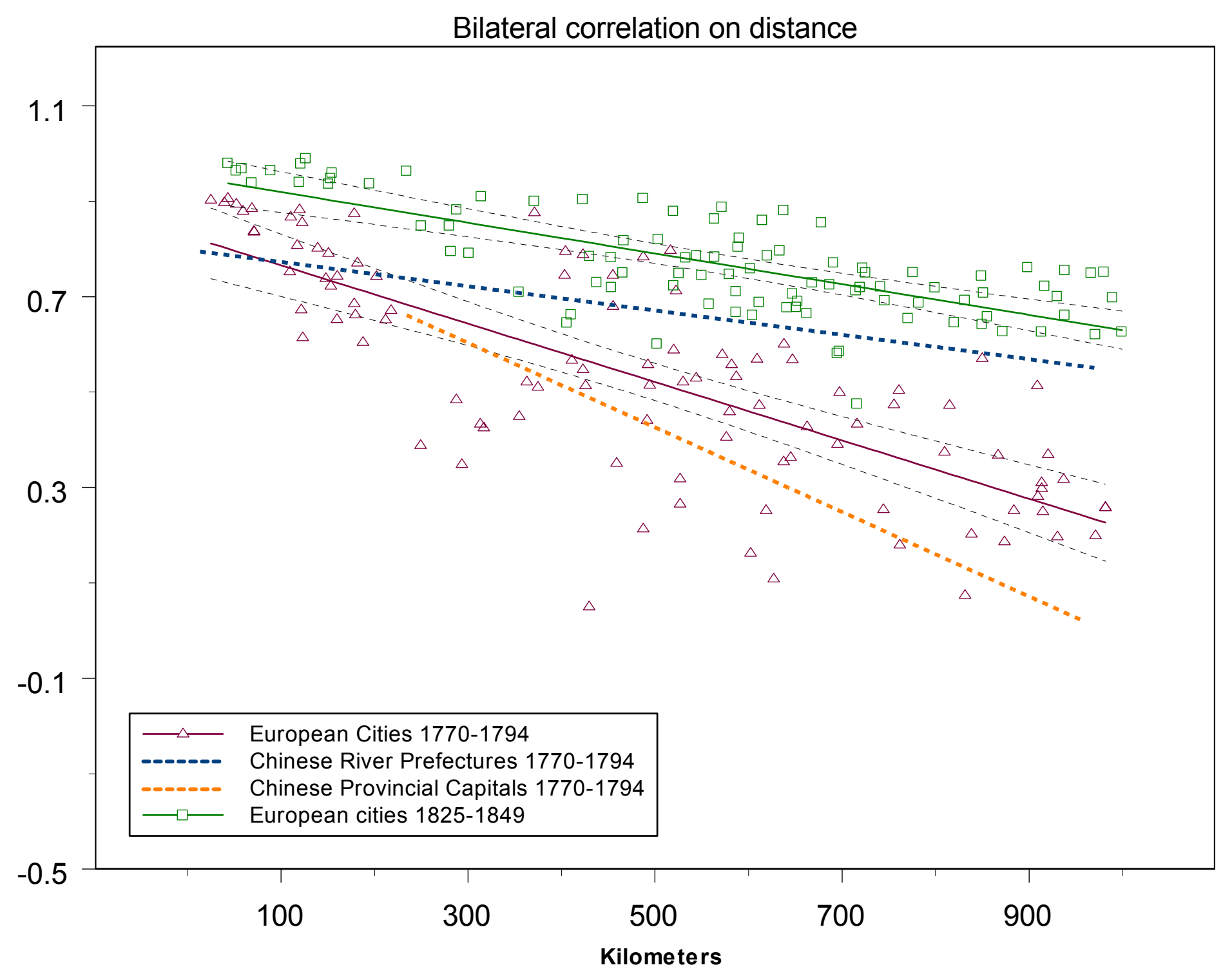


Figure 5. China and Europe, 1770-1794

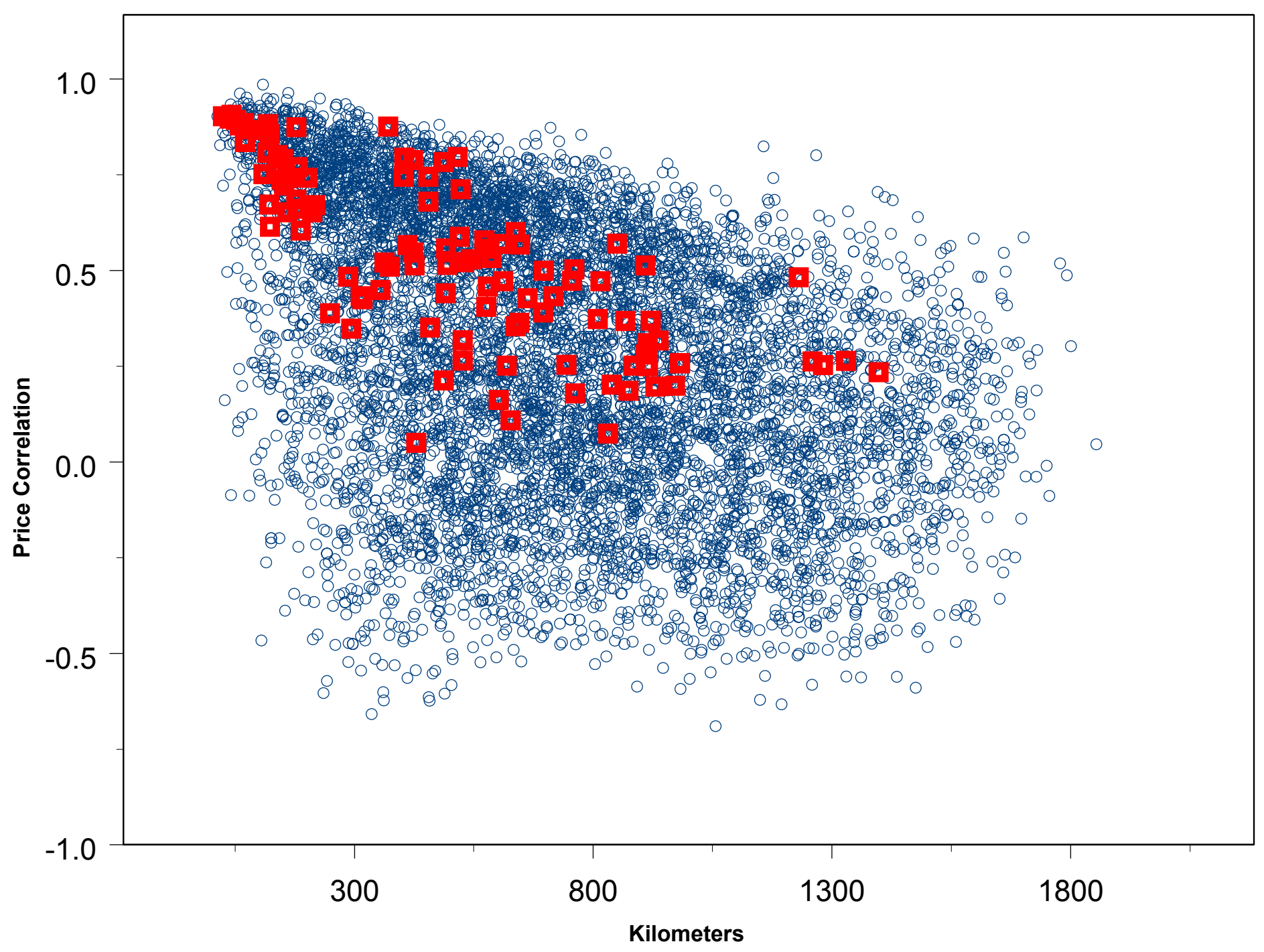


Figure 6. China (1770-1794) and Europe (1825-1849)

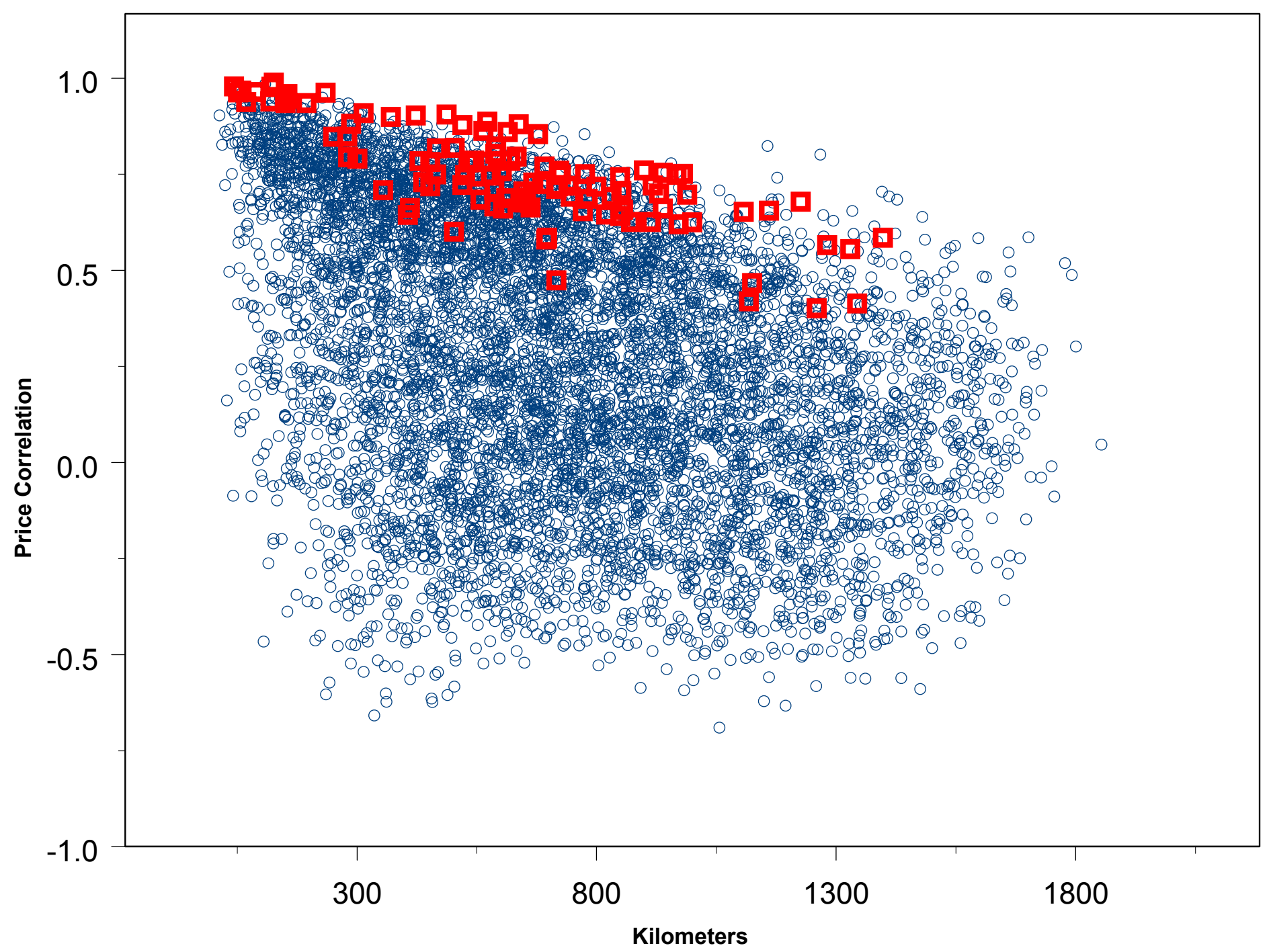


Figure 7. England and the Yangzi Delta, 1770-1794

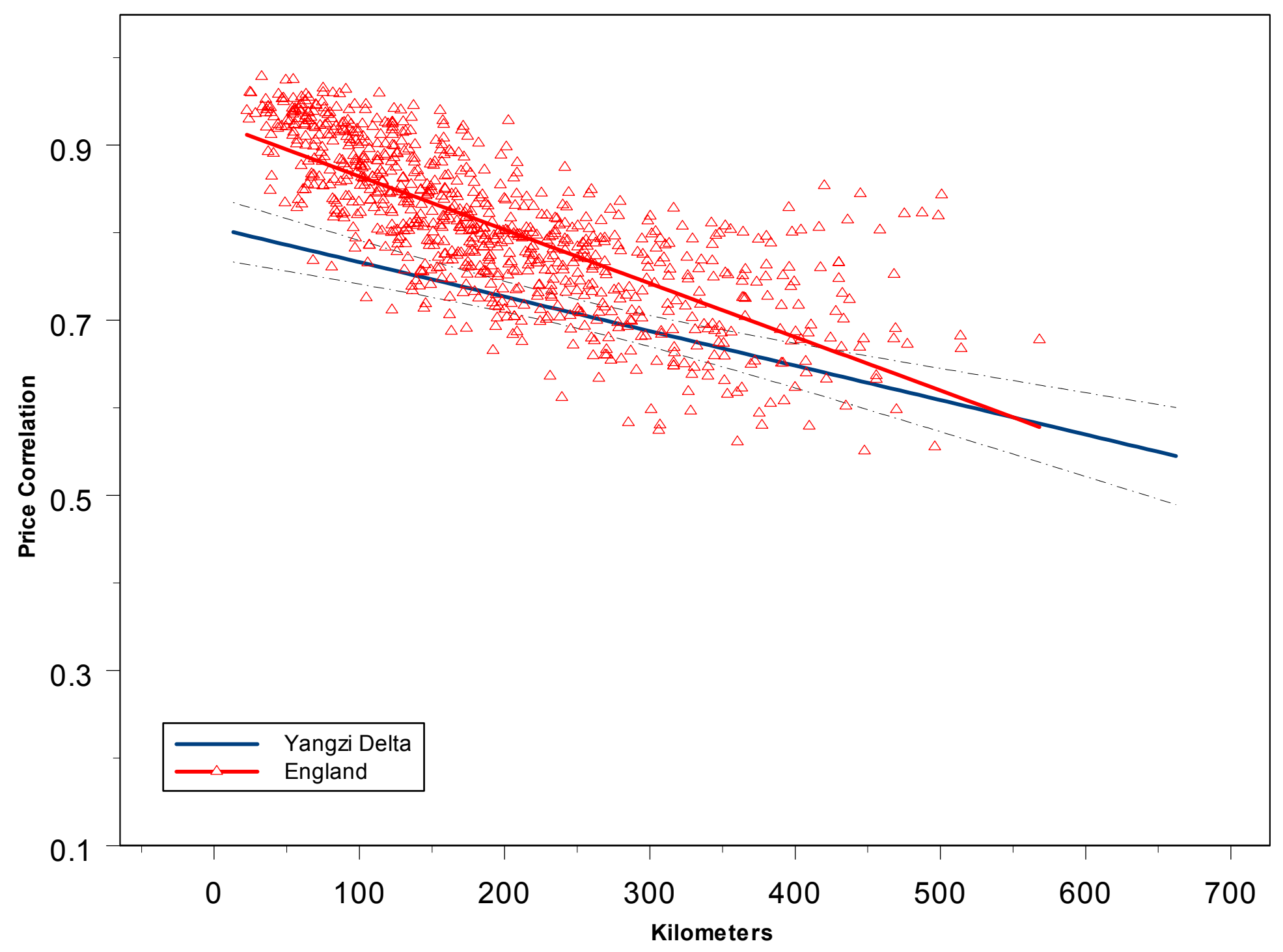


Figure 8. Yangzi Delta and France, 1770-1794

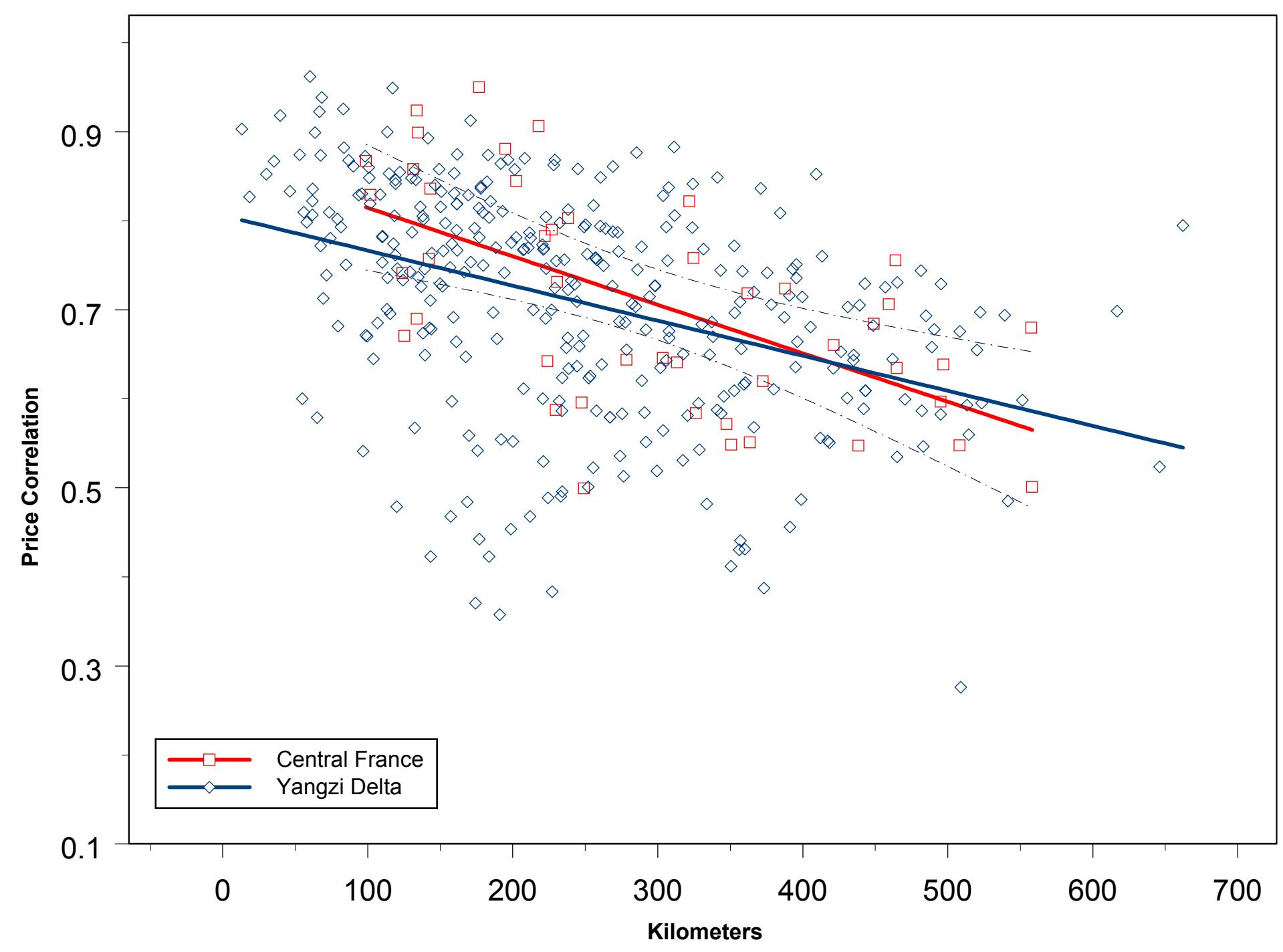


Figure 9. Cointegration in Europe and within England, 1742 to 1795

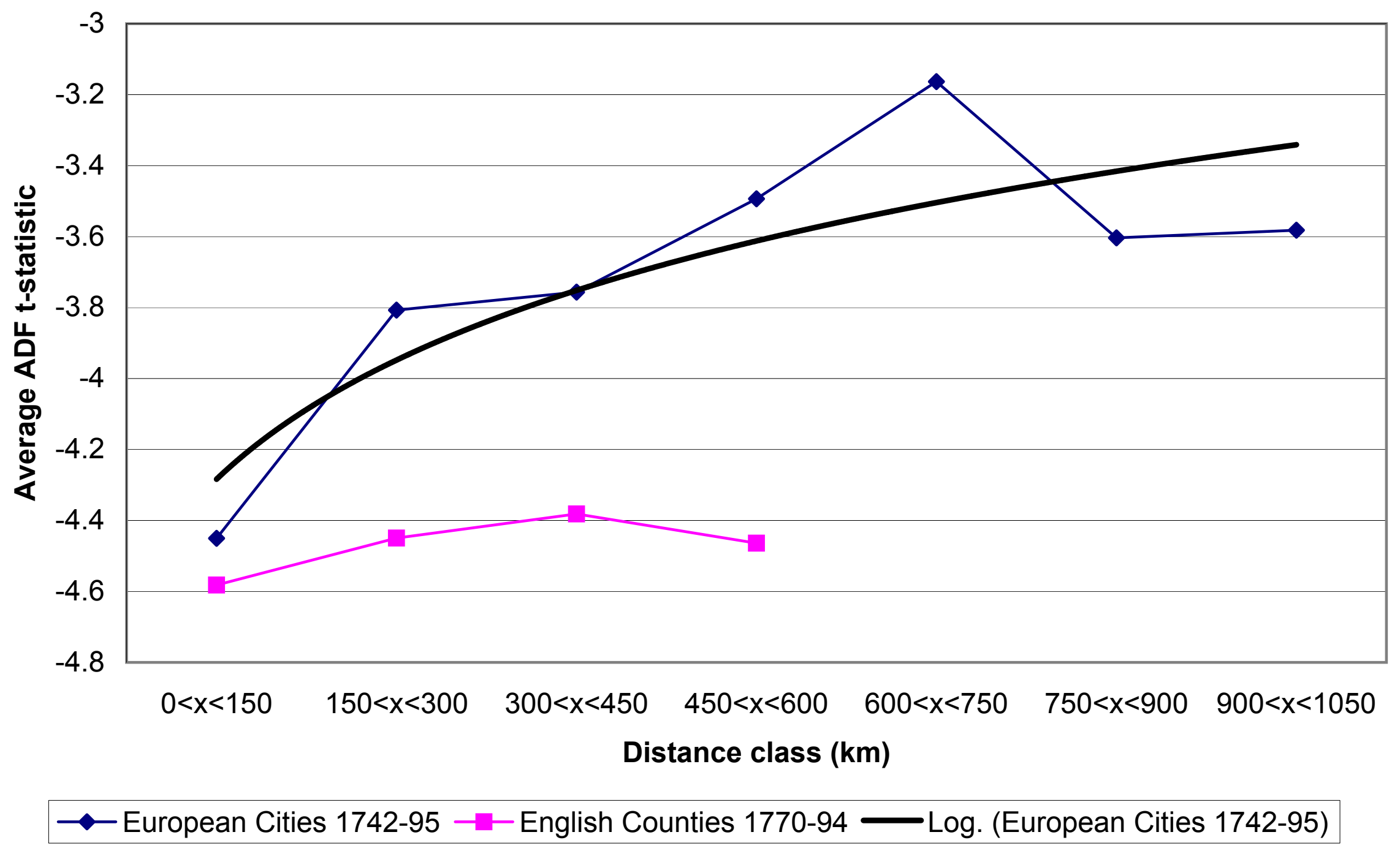




\section{Figure 10: Cointegration in China and Europe, 1742-95}

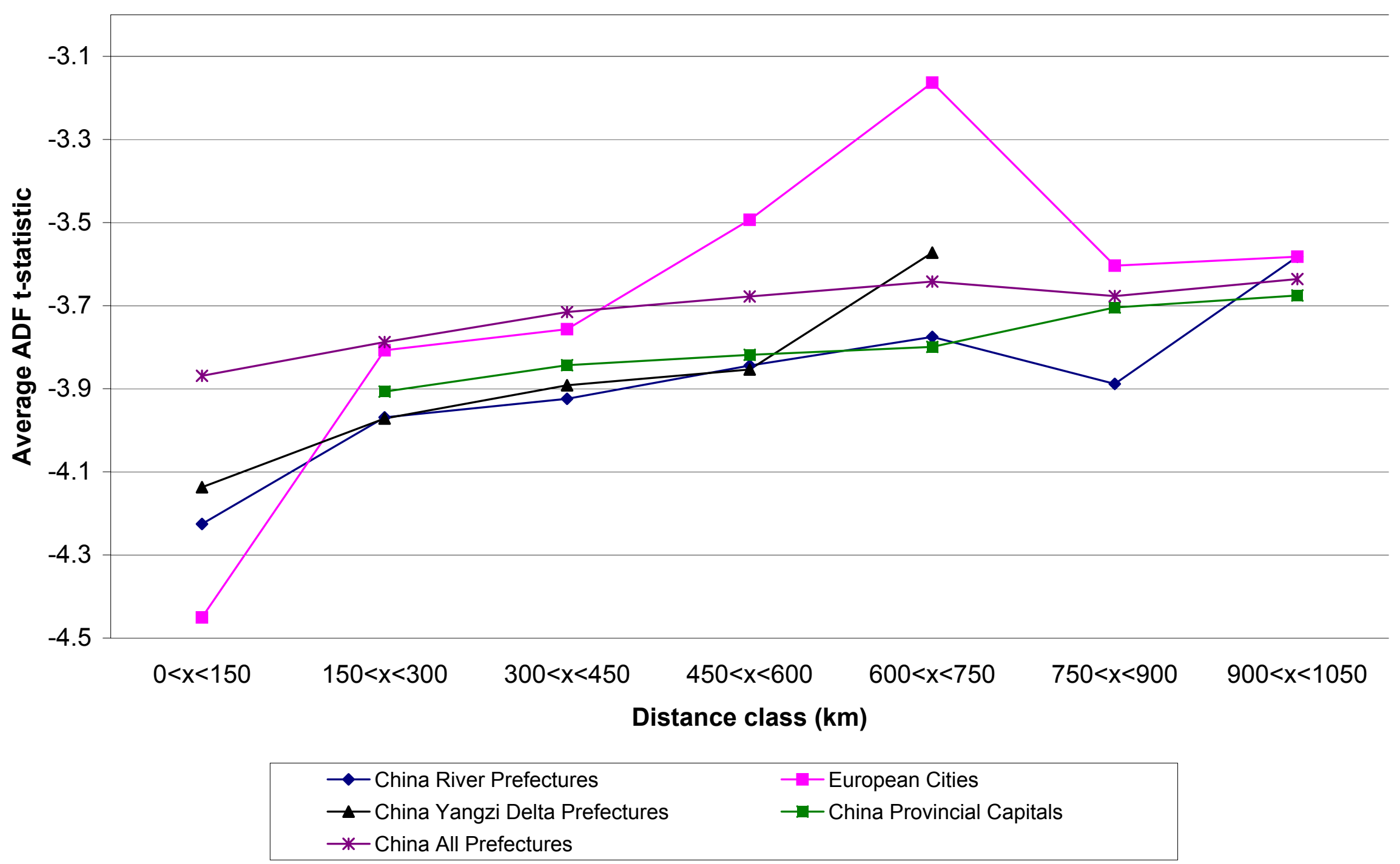


Figure 11. Cointegration in Europe and China: Logarithmic trendlines

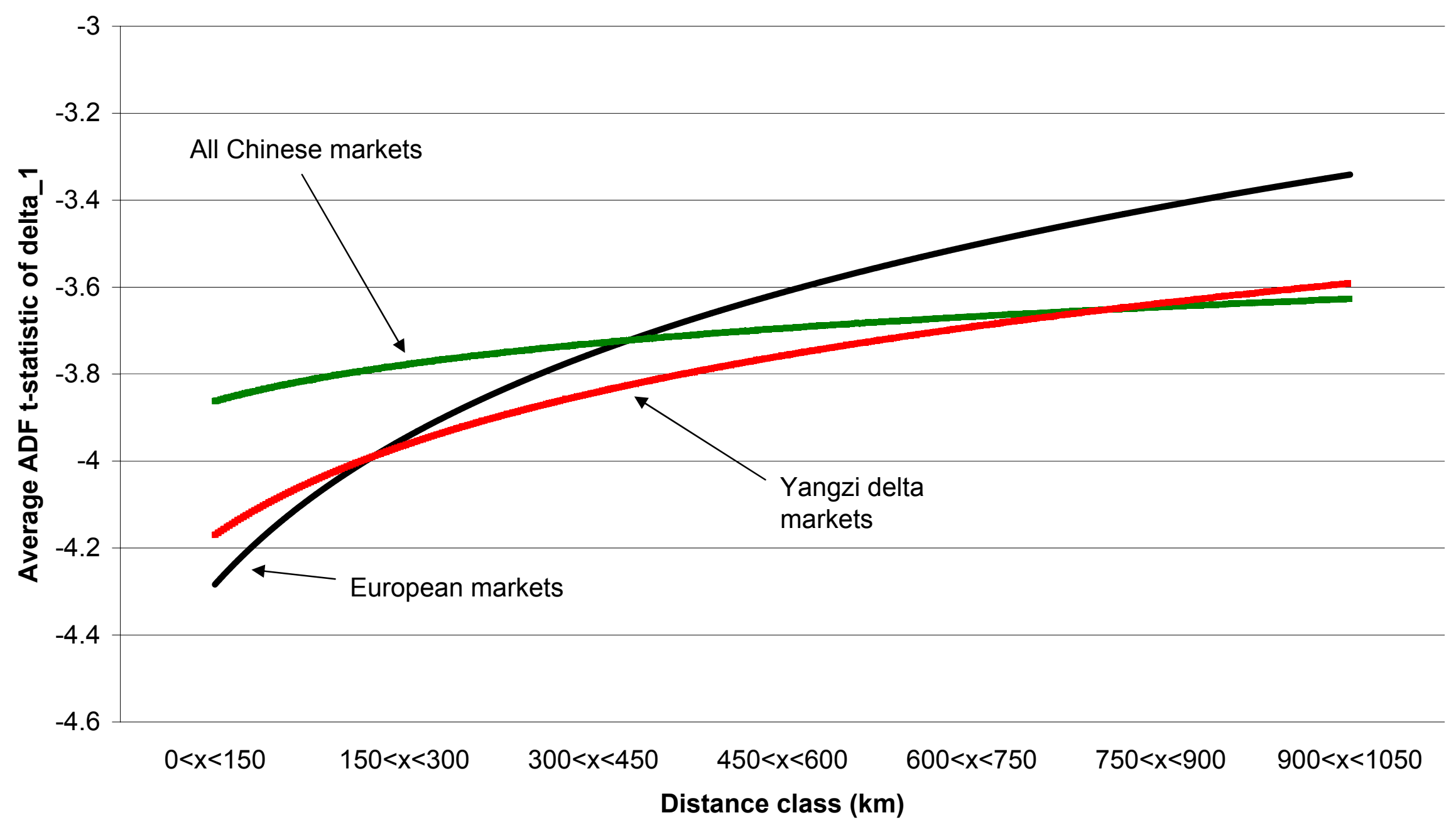


Figure 12. Cointegration in Yangzi Delta, England 18th Century, and Europe 19th Century

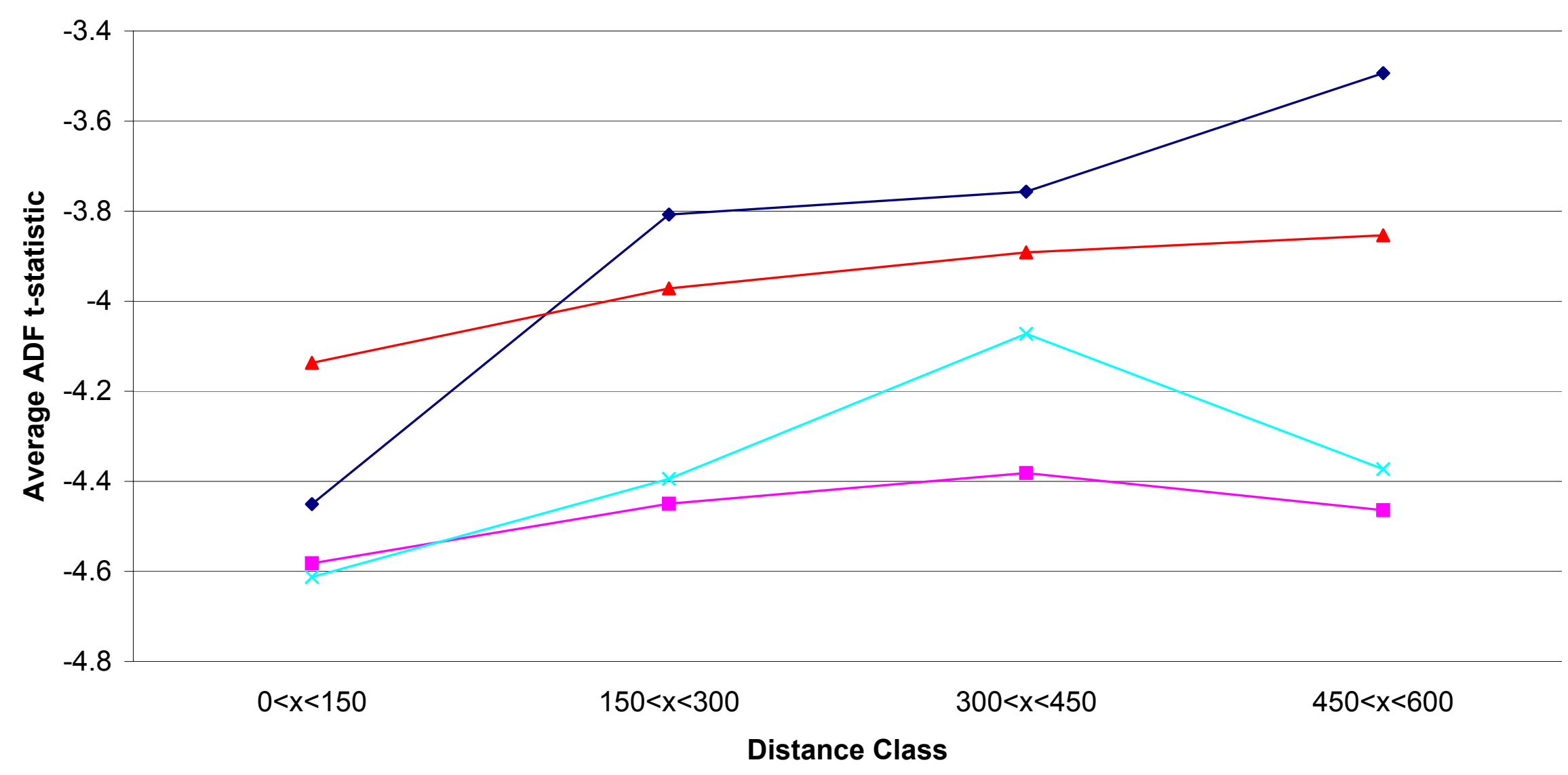

$\begin{array}{ll}\rightarrow-\text { European Cities 1742-95 } & \rightarrow \text { English Counties } 1770-94 \\ \rightarrow-\text { China Yangzi Delta Prefectures } 1742-95 & \star \text { European Cities 1825-49 }\end{array}$




\section{Appendix A: Estimation of Cointegrating Relationships using Maximum Likelihood}

This method, developed by Johansen (1988), is based on systems vector autoregression (VAR) analysis. Consider the case of a first-order VAR:

$$
p_{t}=A_{1} p_{t-1}+\varepsilon_{t},
$$

where $p_{t}$ is the $(n \times 1)$ vector $\left(\mathrm{p}_{1 \mathrm{t}}, \ldots, \mathrm{p}_{\mathrm{nt}}\right)^{\prime}, \varepsilon_{t}$ is the $(n \times 1)$ vector $\left(\varepsilon_{1 \mathrm{t}}, \ldots, \varepsilon_{\mathrm{nt}}\right)^{\prime}$, and $A_{1}$ is a $(n \times n)$ matrix of parameters. Assume that all elements of $y_{t}$ are known to be integrated of order $1(I(1))$. Subtracting $p_{t-1}$ from (A.1) and letting $I$ be an $(n \times n)$ identity matrix yields

$$
\begin{aligned}
\Delta p_{t} & =-\left(I-A_{1}\right) p_{t-1}+\varepsilon_{t} \\
& =\pi p_{t-1}+\varepsilon_{t}
\end{aligned}
$$

Here $\pi$ is the $(n \times n)$ matrix $-\left(I-A_{1}\right)$ and $\pi_{\mathrm{ij}}$ is the element in row $i$ and column $j$ of $\pi$.

In equation (A.2), $\Delta p_{t}$ and $\varepsilon_{t}$ are stationary while $p_{t-1}$ is non-stationary, which means that for consistency the matrix $\pi$ must be less than of full rank (denoted by $r$ ). This appendix considers only the case of $n=2$, which means that $r$ is either 0 or 1 . If the rank of $\pi$ is equal to zero, all elements $\pi_{\mathrm{ij}}$ are equal to zero and (A.2) becomes

$$
\Delta p_{t}=\varepsilon_{t} \Leftrightarrow p_{t}=p_{t-1}+\varepsilon_{t} .
$$

In this case, there is no linear combination of the elements of $p_{t}$ that is stationary, or, $p_{1 t}$ and $p_{2 t}$ are not cointegrated. Alternatively, if $r=1$, there is one cointegrating vector given by either row of $\pi$. Each sequence $\left\{p_{i t}\right\}$ can be written in error-correction form (given by A.2) with non-zero parameters $\pi_{\mathrm{ij}}$ (Granger's representation theorem).

A normalization with respect to $p_{1 t-1}$ allows to write the system (A.2) in terms of parameters $\alpha$ and $\beta$; let $\alpha_{1}=\pi_{11}$ and $\beta_{i j}=\pi_{i j} / \pi_{11}$. The equation for $\Delta p_{1 t}$, e.g., then reads

$$
\Delta p_{1 t}=\alpha_{1}\left(p_{1 t-1}+\beta_{12} p_{2 t-1}\right)+\varepsilon_{1 t} .
$$

In the long-run, the $\left\{p_{i t}\right\}$ will satisfy the relationship

$$
p_{1 t}+\beta_{12} p_{2 t}=0 .
$$

Equation (A.5) corresponds to the cointegrating relationship for Engle and Granger's (1987) model discussed in the text, while the parameter $\alpha$ in equation (A.4) governs the speed of adjustment to equilibrium. An attractive feature of Johansen's (1988) method is that under certain assumptions, one can estimate both the long-run parameters and the short-run parameters by one-step maximum likelihood. ${ }^{1}$

In summary, the Johansen method involves estimating the rank of the matrix $\pi$. In the present context, if the rank of $\pi$ is equal to 0 , there is no cointegration, while if it is equal to 1 , the two series are cointegrated. ${ }^{2}$ The Johansen approach is relatively restrictive, for instance, the errors must be Gaussian (in contrast, Engle and Granger's 1987 method does not rely on that).

\footnotetext{
${ }^{1}$ Also Engle and Granger's method allows estimating the speed-of-adjustment parameters, in a second step.

2 Johansen's method can also be used in the case of higher-order integration and $n>2$.
} 
At the same time, Johansen's method is also powerful in the sense that when it is appropriate, it provides a number of new results.

\section{An Application ${ }^{3}$}

Consider the prefectures Huizhou and Taicang, both located in the expanded Yangzi delta, China's most developed area in the $18^{\text {th }}$ century. Huizhou is located in Anhwei province, and Taicang is located in Jiangsu province, with a distance of about 286 kilometers between them. Taicang is located right on the mouth of the Yangzi River, while Huizhou is further west, and although it is not located directly on the Yangzi River, it is not far from it.

Let the $\log$ rice price in Huizhou be denoted by $p_{1 t}$, while Taicang's is given by $p_{2 t}$. Figure A1 ("Huizhou Prefecture") and Figure A2 ("Taicang Prefecture") show these price series both in levels (on top) and in first differences. The plots suggest that the price levels are nonstationary while the first-differences are stationary, and formal tests confirm this. Cointegration means that there is a linear long-run relationship between the two prices (plus, we allow for a constant, $\beta_{3}$, in the cointegration space):

$$
B_{1} y_{1 t}+B_{2} y_{2 t}+\beta_{3}=0
$$

We perform a number of auxiliary tests that explore whether the price series seem to be suited for an application of Johansen's technique, and which particular model seems most appropriable. ${ }^{4}$ As an example, Figure A3 ("Diagnostic Analysis for Differenced Taicang Price Series") shows some basic characteristics and tests for the differenced Taicang series that help to determine which model should be estimated. Based on this analysis, we make a number of modifications to the base specification. First, we add a seasonal effect that controls for price differences by month (spring or fall), and a number of indicator variables that eliminate the effect of outliers. We denote these deterministic components by $D_{t}$. Second, we include the oncelagged differences of $\Delta p_{t}$, that is, $\Delta p_{t-1}$. The resulting specification is given by

$$
\Delta p_{t}=\Pi p_{t-1}+\Gamma \Delta p_{t-1}+\Phi D_{t}+\varepsilon_{t},
$$

where $\Gamma$ and $\Phi$ are $2 \times 2$ matrices of parameters. If the rank of $\Pi$ is equal to 0 , there is no cointegration, whereas if it is equal to one, the series are cointegrated. The elements of the $\Pi$ matrix are products of $\alpha$ 's and $\beta$ 's, which are the short-run and long-run coefficients, respectively, of the price equilibrium.

To determine the rank of the $\Pi$ matrix, recall that the rank of a matrix is equal to the number of its eigenvalues that are different from zero. Johansen has developed several tests to determine whether - with $n=2$ - one eigenvalue is sufficiently far away from zero so that one

\footnotetext{
${ }^{3}$ This is not meant to be representative; while we have studied cointegration among many prefectures using Johansen's technique, we have not done so for all 7260 bilateral relations. However, see the Engle-Granger results based on all 7260 bilateral relations in Figure 11 above.

${ }^{4}$ These tests analyze the degree of serial and cross-series correlation, whether the errors appear to be normally distributed, and whether there appears to be autoregressive conditional heteroskedasticity (ARCH) effects. The models that we consider differ in (i) what lag length (the number of differenced lags on the right hand side) to use, (ii) whether to include seasonal effects and other deterministic components, (iii) how to identify and to treat outliers, and other factors. See Maddala and Kim (1998) for a discussion.
} 
can conclude that the rank of the $\Pi$ matrix is one. The larger eigenvalue of the matrix $\Pi$ in equation (A.7) is estimated to be 0.254 , with a ('trace') test statistic of 52.51. The relevant critical value for the trace test is far lower than that (with a value of 17.79), which means that $r=$ 1 is accepted, that is, the two series are cointegrated. ${ }^{46}$ Figure A4 ("The Estimated Cointegrating vector between the Huizhou and Taicang Price Series") shows the estimated cointegrating vector $B_{1} p_{1 t}+B_{2} p_{2 t}$. The difference between the top and the bottom part of the figure is that the bottom takes the deterministic components and the lagged difference $\Delta p_{t-1}$ into account whereas the top does not. The plots suggest that at least for the larger parts of the time series, the estimated linear combination of the two prices is stationary.

A second question that can be addressed is whether an adjusted law of one price is holding among these prefectures. Normalizing equation (A.6) by setting $B_{1}$ to 1 - the parameter $B_{1}$ and $B_{2}$ are not separately identified - this amounts to testing whether in the long-run, $B_{2}$ is equal to 1 , or, the price in Huizhou is equal to the price in Taicang (up to the constant $\beta_{3}$ ). In that case, (A.6) becomes $p_{1 t}=p_{2 t}-\beta_{3}$.

In the unrestricted regression, $B_{2}$ is estimated at 0.989 , and consequently, the hypothesis that $B_{2}=1$ cannot be rejected at a $5 \%$ level ( $p$-value of $3 \%$ ). This means that there is evidence for the (adjusted) law of one price. Moreover, the constant $\beta_{3}$ is estimated to equal 0.048 , suggesting that the long-run price in Taicang, at the mouth of the Yangzi, is above the long-run price in Huizhou. The finding is very plausible, because on average, grain prices in China were increasing as one moves from the inland regions of China's west down the river to the larger cities of the Yangzi Delta.

Turning to the short-run dynamics, there are two questions of interest: first, do prices in both markets respond to the respective other price, or is it primarily the change in one price that brings the markets back to long-run equilibrium? This depends on the signs of the coefficients $\alpha$. In this case, $\alpha_{1}$, in the $\Delta p_{1 t}$ equation, is estimated to be significantly negative, whereas $\alpha_{2}$ in the $\Delta p_{2 t}$ equation is positive. This is plausible because stability of the long-run equilibrium requires that an above-equilibrium value of $y_{1 t}$ triggers a subsequent decline of $p_{1 t}\left(\alpha_{1}\right.$ negative), and/or a below-equilibrium value of $p_{2 t}$ triggers a rise in $p_{2 t}\left(\alpha_{2}\right.$ positive). Here, adjustment towards the equilibrium works through both markets (neither of the market prices is weakly exogenous).

The second question is: how long does it take until a shock to the long-run equilibrium is absorbed? This can be gauged by looking at the size of the $\alpha$ 's. The point estimates for $\alpha_{1}$ and $\alpha_{2}$ are -0.228 and 0.291 , respectively. These numbers, of around 0.25 in absolute value, translate into a half-life of a shock of about 0.5 years for these two markets. ${ }^{47}$ For comparison, Persson (1999, 98-100) estimates comparable half-lives for a number of grain markets in Europe

\footnotetext{
${ }^{46}$ The exact critical value for this test might be somewhat different, both because it is an asymptotic value (here, $\mathrm{T}=108$ ), and because we include some additional deterministic components. In any case, given the large test statistic of 52.51 (relative to the approximate critical value of 17.79), qualitatively, this will not matter.

${ }^{47}$ We use prices at semi-annual frequency (one period lasts six months). At the same time, note that we use monthly data, the same frequency that is employed for the European estimates discussed in the following; Gonzalo (1993) and Taylor (2001) discuss the consequences of temporal aggregation for the properties of some estimators.
} 
and finds that the duration in the $16^{\text {th }}$ to $18^{\text {th }}$ centuries was $11 / 2$ to 3 years; and the half life of a price deviation does not fall to 3 to 4 months until the mid-19th century.

\section{Appendix B: Comparing historical weather patterns in China and Europe}

For China, the weather data available to us is an indicator of rainfall and wetness in a given harvest year. Systematic rainfall recording began as early as the Tang Dynasty (618-907 A.D.), and from at least the 17 th century the collection of rainfall and weather reports at the county level had become standard government practice (Wilkinson 1969). Our source for historical weather data are the weather maps in the State Meteorological Administration (1981). The maps give weather data throughout China for each year for 120 "stations", where one station corresponds to one or two of our prefectures. It is a discrete indicator of the degree of rainfall relative to what is considered normal for that region. The indicator, $\mathrm{R}_{\mathrm{nt}}$, ranges from 1 (severe droughts) to 5 (heavy rains and floods), and normal conditions are given by $R_{n t}=3$. The information is hand-coded from the weather maps to compute the weather correlations between any two prefectures.

For Western and Central Europe before 1300 A.D., there are reports of natural disasters, and by 1800 A.D. there are almost complete descriptions of monthly weather, although crossborder (international network) weather observations before 1860 were still rare (Pfister 2002). The exact relationship between climate and agricultural output is complicated, but it is clear that both extreme temperatures as well as extreme humidity tend to lead to bad harvests. Moreover, humidity and temperatures in different years or in different cities are correlated. ${ }^{7}$ This means that we can employ the temperature data for 8 European cities available to us to compare the spatial weather patterns in Europe with those in China. ${ }^{8}$ For each of the eight European cities, we have re-classified the weather data from temperature in degrees Celsius into five discrete classes, 1 to 5 , and computed for each city pair the correlation of weather. ${ }^{9}$

The regressions presented in Table B1 compare weather correlations in China and Europe as a function of distance. We see that throughout weather correlations in Europe were higher than they were in China, indicated by the higher intercepts for the former sample (China: 0.39 to 0.62 , versus 0.83 to 1.17 for Europe). This in itself suggests that our evidence on price correlation might be affected by spatial patterns of weather (and not of arbitrage and trade) to a relatively greater extent in Europe, or put differently, without controlling for weather we have stacked the odds against finding China ahead in terms of market efficiency. However, it may be that the spatial correlation of humidity (used for China) and of temperature (used for Europe) is just different, and this may explain in part why we estimate a higher level of weather correlations for Europe.

\footnotetext{
${ }^{7}$ See Baten (2000) for more discussion.

${ }^{8}$ The temperature data was provided by Rüdiger Glaser (see Glaser 2001); thanks to Jörg Baten for sharing the data with us. The cities are Paris, Vienna, Munich, De Bilt (the Netherlands), Nottingham (as Central England), Berlin, Basle (as Switzerland), and Stockholm (as Sweden).

${ }^{9}$ We replicate the frequencies that are present in the data for China (1770-1794): $\mathrm{R}_{\mathrm{nt}}=1,2,3,4$, and 5 with probabilities of $5.7 \%, 28.1 \%, 46.5 \%, 15.3 \%$, and $4.5 \%$, respectively.
} 
Another question thus is how weather correlations changed with distance in the two continents. It turns out that there is no clear difference between China and Europe. In the preferred specification for the European sample (in terms of $\bar{R}^{2}$ ), we estimate a value of -0.243 on log distance for Europe, while for China it is smaller in absolute value (at -0.195). However, the $95 \%$ confidence interval of the estimate for Europe is $(-0.310,-0.177)$, which covers the point estimate for China. Moreover, one may want to drop Stockholm from the sample because its location is substantially to the North of our core price series sample. That alone brings the distance coefficient rises to -0.186 , less in absolute value than the estimate for China while at the same time increasing the $\bar{R}^{2}$ (see specifications 4 and 2a, respectively). In addition, the preferred specification for the Chinese sample has both log distance and its square, and for this specification distance has the expected effects for China (linear: negative, squared: positive), while for Europe distance has no significant effect.

On the bottom of the table, the predicted level of weather correlations in China and Europe is reported based on the OLS regressions. It is clear from these figures that the predicted weather correlation in Europe was higher than in China, while if one focuses on changes in weather correlation (moving from $300 \mathrm{~km}$ to $600 \mathrm{~km}$ e.g.), the magnitudes are roughly comparable. $^{10}$

Overall, this analysis shows that the influence of weather is unlikely to favor China over Europe in our comparison. First, the changes in weather accompanied by changes in distance were comparable in China and Europe. Second, we estimate that the level of weather correlations was substantially stronger in Europe than in China, and to the extent that this is not entirely due to differences in temperature versus humidity patterns, the analysis tends to favor Europe over China.

\footnotetext{
${ }^{10}$ Finally, the remaining two specifications indicate that our results do not seem to be driven by the particulars of China's weather distribution during 1770-94 (specification 5) or the fact that the minimum bilateral distance in our China is smaller than in our European sample (12 kilometers versus 265 kilometers; specification 6).
} 
Figure A.1. Huizhou Prefecture

L2
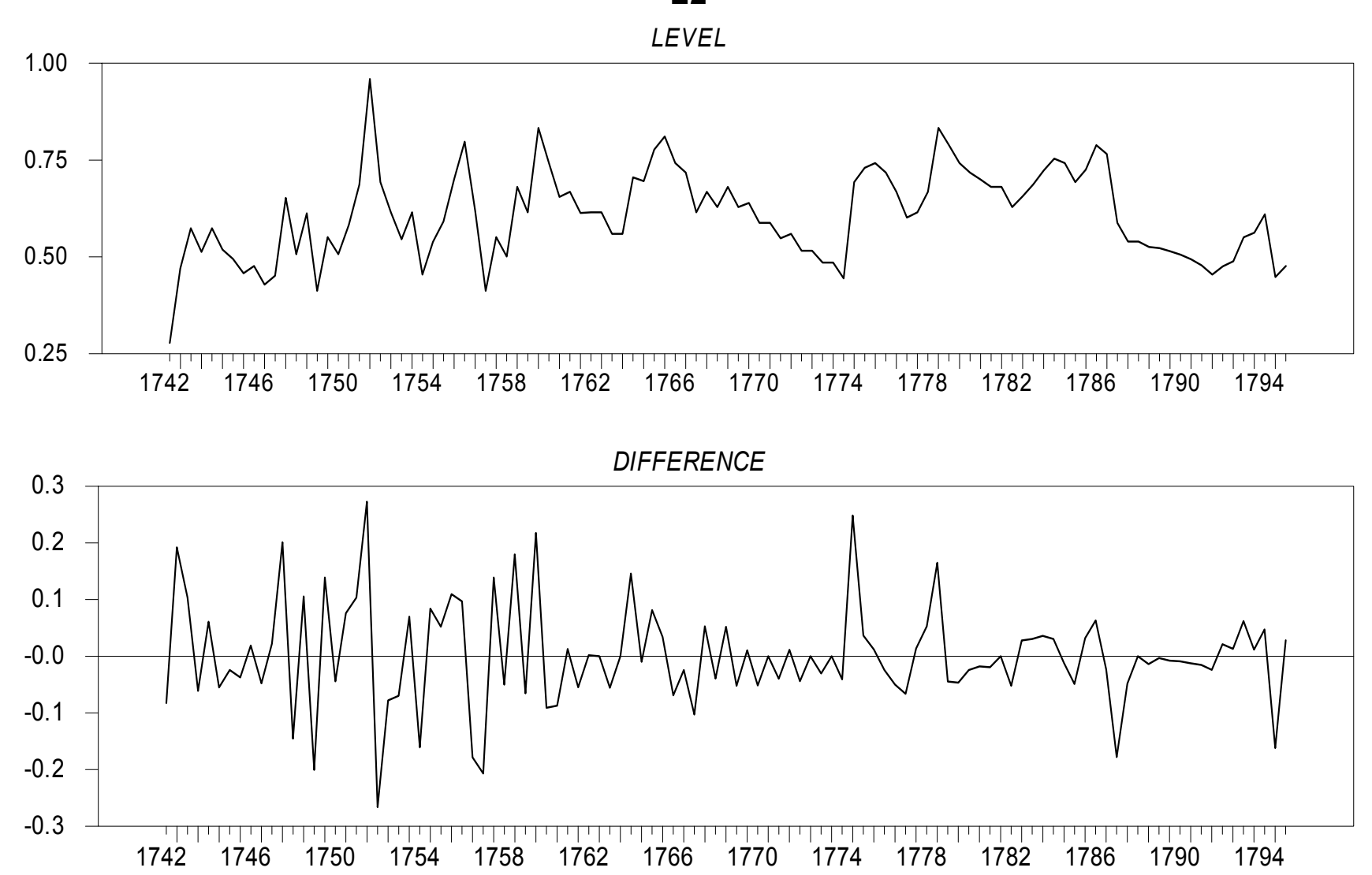
Figure A.2 Taicang Prefecture

L94

LEVEL

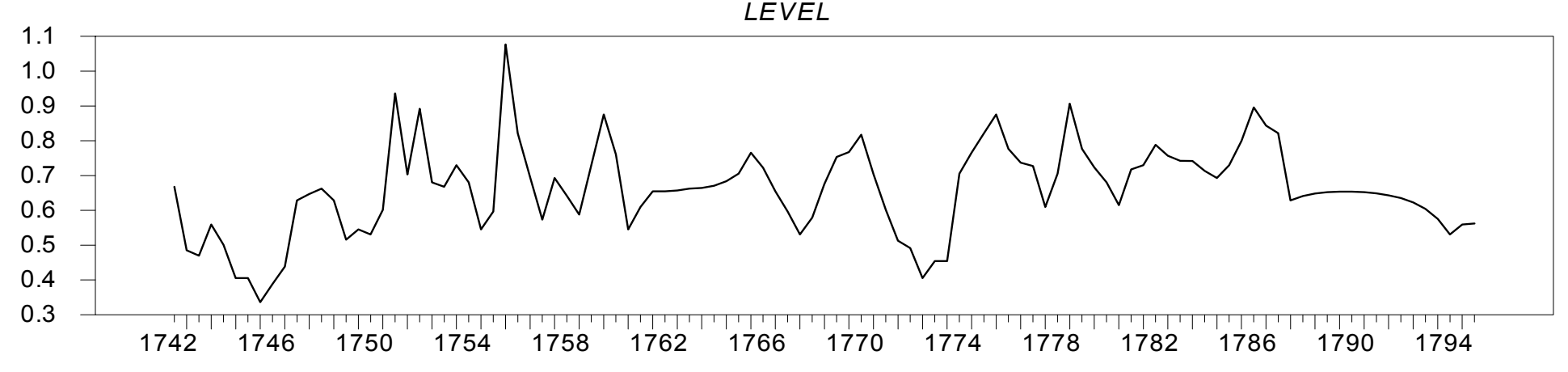

DIFFERENCE

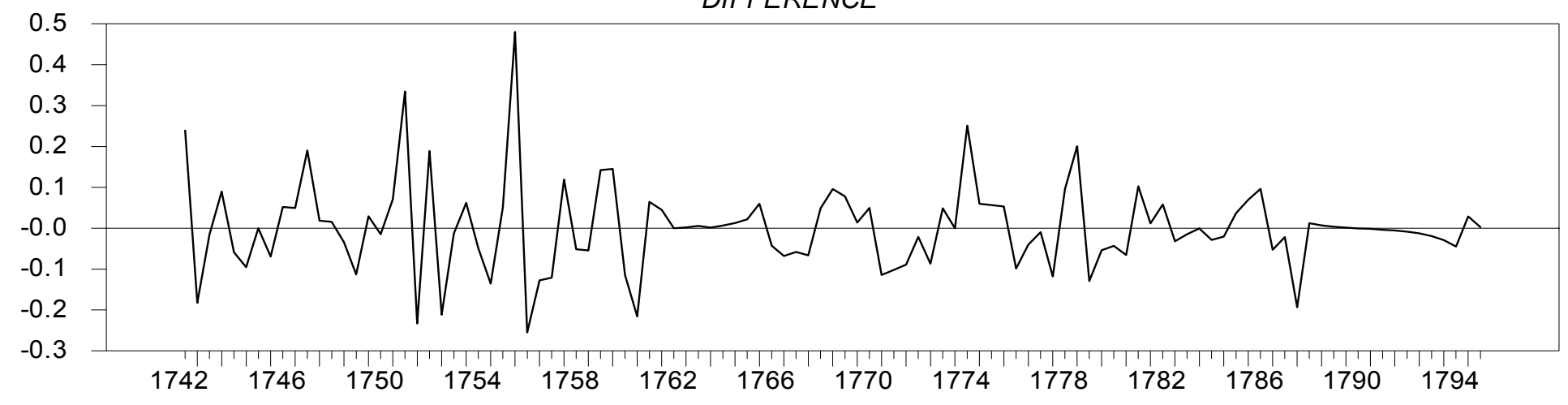


Figure A.3 Diagnostic Analysis for Differenced Taicang Price Series
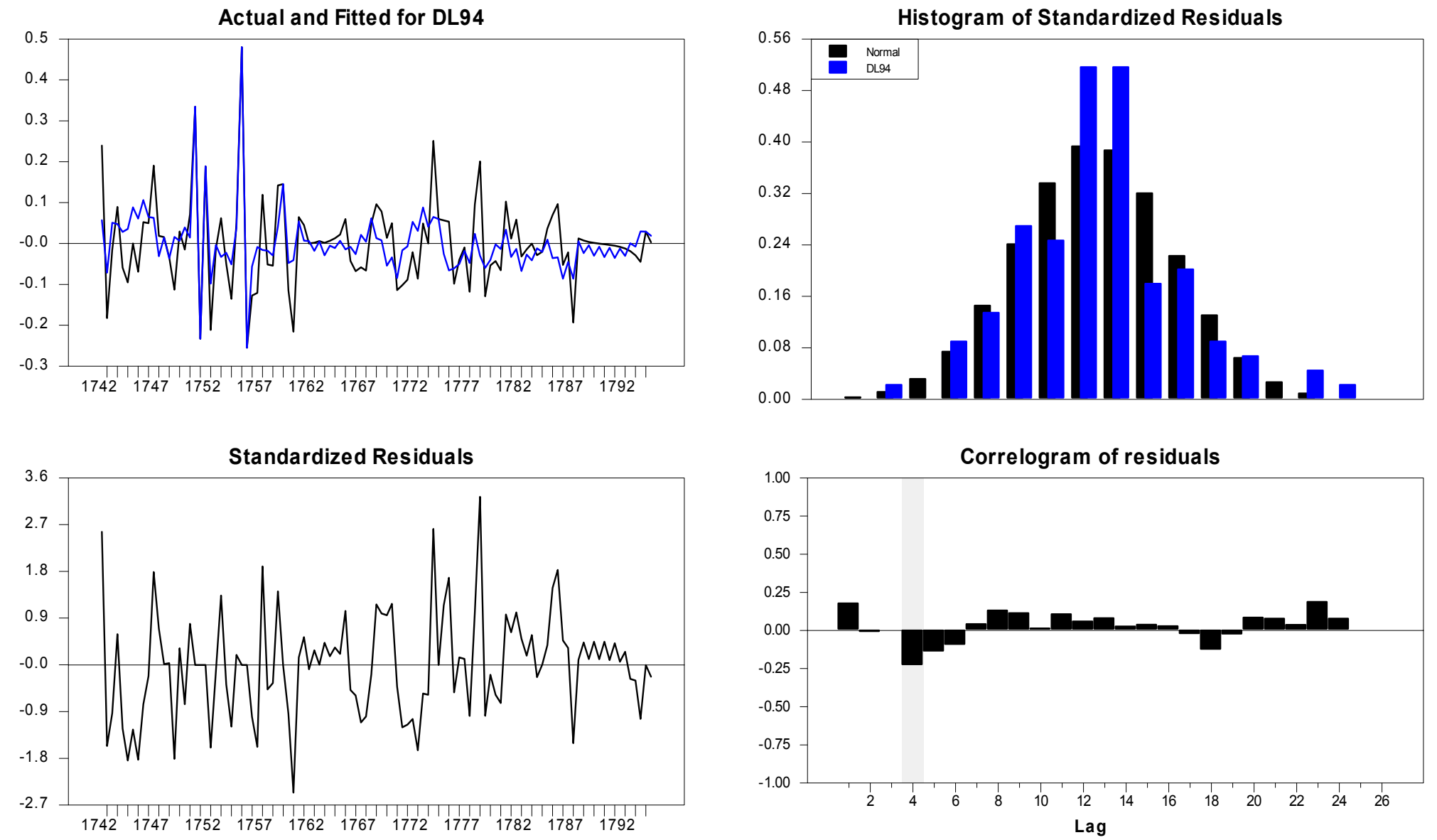
Figure A.4 The Estimated Cointegrating Vector between the Huizhou and Taicang Price Series.

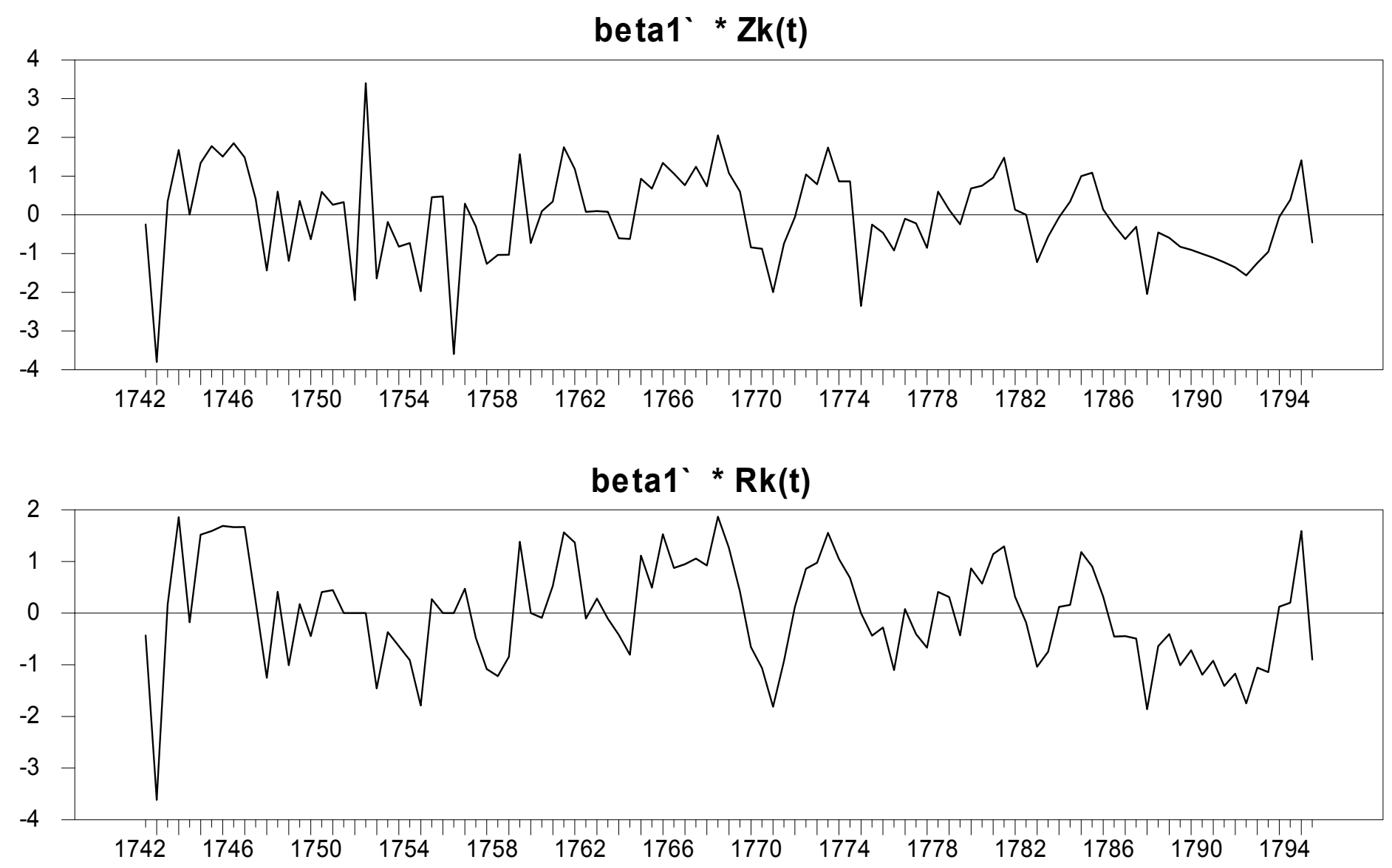


Table B.1: The spatial correlation of weather in Europe and China, 1770 to 1794

Dependent variable: Bilateral weather correlation

\begin{tabular}{|c|c|c|c|c|c|c|c|c|c|}
\hline & (1a) & (1b) & (2a) & (2b) & (3a) & (3b) & (4) & (5) & (6) \\
\hline & China & Europe & China & Europe & China & Europe & $\begin{array}{c}\text { Europe } \\
\text { w/o Stockholm }\end{array}$ & $\begin{array}{c}\text { Europe } \\
\text { Alt. Dist'n } n^{\star \star *}\end{array}$ & $\begin{array}{c}\text { China } \\
\text { Distance }>265\end{array}$ \\
\hline Intercept & $\begin{array}{l}0.392^{\star *} \\
(0.007)\end{array}$ & $\begin{array}{l}0.832^{\star *} \\
(0.034)\end{array}$ & $\begin{array}{l}0.539^{* *} \\
(0.010)\end{array}$ & $\begin{array}{l}1.116^{* *} \\
(0.065)\end{array}$ & $\begin{array}{l}0.628^{* *} \\
(0.017)\end{array}$ & $\begin{array}{l}0.890^{*} \\
(0.387)\end{array}$ & $\begin{array}{l}1.024^{\star *} \\
(0.068)\end{array}$ & $\begin{array}{l}1.166^{* *} \\
(0.071)\end{array}$ & $\begin{array}{l}0.591^{* *} \\
(0.049)\end{array}$ \\
\hline Distance & $\begin{array}{c}-0.029^{\star *} \\
(0.001)\end{array}$ & $\begin{array}{c}-0.025^{\star *} \\
(0.004)\end{array}$ & & & & & & & \\
\hline \multicolumn{10}{|l|}{ Distance sq. } \\
\hline Log Distance & & & $\begin{array}{c}-0.197^{\star *} \\
(0.005)\end{array}$ & $\begin{array}{c}-0.243^{* *} \\
(0.032)\end{array}$ & $\begin{array}{c}-0.362^{* *} \\
(0.022)\end{array}$ & $\begin{array}{l}-0.026 \\
(0.372)\end{array}$ & $\begin{array}{c}-0.186^{\star *} \\
(0.033)\end{array}$ & $\begin{array}{l}-0.260^{\star *} \\
(0.036)\end{array}$ & $\begin{array}{l}-0.354^{\star *} \\
(0.051)\end{array}$ \\
\hline Log Distance sq. & & & & & $\begin{array}{l}0.057^{* *} \\
(0.007)\end{array}$ & $\begin{array}{l}-0.050 \\
(0.085)\end{array}$ & & & $\begin{array}{l}0.061^{\star *} \\
(0.013)\end{array}$ \\
\hline R-bar squared & 0.158 & 0.601 & 0.236 & 0.611 & 0.254 & 0.601 & 0.629 & 0.572 & 0.065 \\
\hline \# of obs. & 7260 & 28 & 7260 & 28 & 7260 & 28 & 21 & 28 & 6397 \\
\hline \multicolumn{10}{|l|}{$\begin{array}{l}\text { Implied weather } \\
\text { correlation at }\end{array}$} \\
\hline $300 \mathrm{~km}$ & 0.305 & 0.757 & 0.323 & 0.899 & 0.299 & 0.890 & 0.820 & 0.880 & 0.276 \\
\hline $600 \mathrm{~km}$ & 0.218 & 0.682 & 0.186 & 0.731 & 0.162 & 0.890 & 0.691 & 0.700 & 0.153 \\
\hline $900 \mathrm{~km}$ & 0.131 & 0.607 & 0.106 & 0.632 & 0.108 & 0.890 & 0.615 & 0.595 & 0.108 \\
\hline
\end{tabular}

OLS regressions with heteroskedasticity-consistent standard errors in parentheses

Europe is the cities Paris, Vienna, Munich, De Bilt, Nottingham, Berlin, Basle, and Stockholm China is 121 prefectures

${ }^{* *}(*)$ indicates that a coefficient is significantly different from 0 at a $1 \%(5 \%)$ level

*** The European data is re-coded to match the distribution of weather in China during 1496-1916 (not 1770-94) 